\title{
Use of a Droplet Platform to Optimize Pd-Catalyzed C-N Coupling Reactions Promoted by Organic Bases
}

\author{
Lorenz M. Baumgartner, ${ }^{\ddagger \S}$ Joseph M. Dennis, ${ }^{\rrbracket}, \S$ Nicholas A. White, \\ Stephen L. Buchwald ${ }^{\text {I* }^{*}}$ and Klavs F. Jensen ${ }^{*^{*}}$ \\ ${ }^{\ddagger}$ Department of Chemical Engineering, Massachusetts Institute of Technology, Cambridge, \\ Massachusetts 02139, United States \\ ॠ Department of Chemistry, Massachusetts Institute of Technology, Cambridge, Massachusetts 02139, \\ United States \\ ${ }^{\S}$ These authors contributed equally to this work
}

*Correspondence to: kfjensen@mit.edu and sbuchwal@mit.edu 


\section{$\underline{\text { Table of Contents }}$}

General Information .............................................. S3

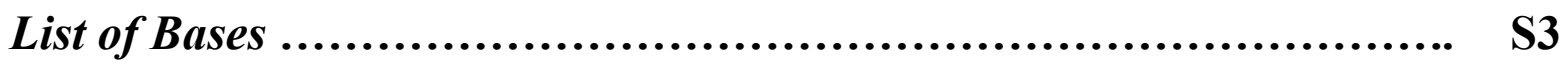

Calculation of Base Prices.......................................... S4

Preparation of Starting Materials and Product Standards................. S5

Preparation of Precatatlysts......................................... S6

Characterization Data for Precatalysts............................ S7

General Procedure for Reaction Screening............................ S10

Use of the Microfluidic Optimization Platform

Optimization Algorithm......................................... $\quad \mathrm{S12}$

General Procedure for Online Optimization....................... S14

Optimization System ........................................... S15

Data Analysis ................................................ $\quad \mathbf{S 1 9}$

Optimization Results and Data Points............................ S21

Batch Scale Up Using an AlPhos Precatalyst ........................... S27

NMR Data for Precatalysts and Products .............................. S28 


\section{$\underline{\text { General Information }}$}

Unless noted, all chemicals obtained from commercial sources, were stored at room temperature, and were used as received. All reactions were carried out under an atmosphere of nitrogen using standard Schlenk techniques or in a nitrogen-filled glovebag or glovebox. Anhydrous 2-methyl tetrahydrofuran (2-MeTHF) and dimethylsulfoxide (DMSO) were purchased from Sigma-Aldrich in Sure-Seal ${ }^{\mathrm{TM}}$ bottles and were degassed prior to use. $\mathrm{CDCl}_{3}$ was purchased from Cambridge Isotope Laboratories. Other reagents were either prepared according to referenced literature procedures or were purchased from chemical suppliers (Sigma-Aldrich, Combi-Blocks, Alfa Aesar, or TCI-America) and were used as received. Bases BTMG, BTTP, and $\mathrm{P}_{2}$ Et, were stored in a nitrogen-filled glovebox in a freezer $\left(-30^{\circ} \mathrm{C}\right)$. Isolated compounds were purified by flash chromatography using Silicycle SiliaFlashP60 (230-400 mesh) silica gel with the aid of a Biotage SP4 instrument. ${ }^{1} \mathrm{H},{ }^{13} \mathrm{C},{ }^{19} \mathrm{~F}$, and ${ }^{31} \mathrm{P}$ spectra were recorded on a Bruker Avance-400 $\mathrm{MHz}$ spectrometer. ${ }^{1} \mathrm{H}$ and ${ }^{13} \mathrm{C}$ spectra were calibrated using residual chloroform as an internal reference $\left(\mathrm{CHCl}_{3}: \delta 7.26 \mathrm{ppm}\right.$ and $\delta 77.36 \mathrm{ppm}$, respectively). ${ }^{19} \mathrm{~F}$ NMR spectra were calibrated to an external standard of neat $\mathrm{CFCl}_{3}(\delta 0.0 \mathrm{ppm}) .{ }^{31} \mathrm{P}$ NMR spectra were calibrated to an external standard of $\mathrm{H}_{3} \mathrm{PO}_{4}(\delta 0.0 \mathrm{ppm})$. The following abbreviations were used to explain multiplicities: $\mathrm{s}$ $=$ singlet, $\mathrm{bs}=$ broad singlet, $\mathrm{d}=$ doublet, $\mathrm{t}=$ triplet, $\mathrm{q}=$ quartet, $\mathrm{m}=$ multiplet. HRLC data were Bruker Daltonics APEXIV 4.7 Tesla Fourier transform ion cyclotron resonance mass spectrometer (FT-ICR-MS). Melting points were obtained using a Stanford Research Systems EZ-Melt melting point apparatus.

\section{List of Bases}

B1: triethyl amine (TEA)

B2: 1,1,3,3-tetramethylguanidine (TMG)

B3: 2-tert-butyl-1,1,3,3-tetramethylguanidine (TMG)

B4: 1,8-Diazabicyclo[5.4.0]undec-7-ene (DBU)

B5: 7-Methyl-1,5,7-triazabicyclo[4.4.0]dec-5-ene (MTBD)

B6: tert-butylimino-tri(pyrrolidino)phosphorene (BTTP)

B7: 1-Ethyl-2,2,4,4,4-pentakis(dimethylamino)- $2 \lambda^{5}, 4 \lambda^{5}$-catenadi(phosphazene) $\left(\mathrm{P}_{2} \mathrm{Et}\right)$ 


\section{Calculation of Base Prices}

All prices were calculated from the largest amount available from common chemical suppliers as determined from eMolecules and MilliporeSigma (Table S1). Volumes, masses, and prices were collected on $04 / 08 / 2019$.<smiles>CCN(CC)CC</smiles>

TEA (B1)

$\mathrm{pK}_{\mathrm{BH}^{+}}=8.6$

$\$ 0.01 / \mathrm{mmol}$<smiles>CN1CCCN2CCCN=C12</smiles>

MTBD (B5) $\mathrm{pK}_{\mathrm{BH}}{ }^{+}=25.5$

$\$ 7.80 / \mathrm{mmol}$<smiles>CN(C)C(=N)N(C)C</smiles>

TMG (B2)

$\mathrm{pK}_{\mathrm{BH}}{ }^{+}=23.3$

$<\$ 0.01$<smiles>CN(C)C(=NC(C)(C)C)N(C)C</smiles>

BTMG (B3)

$\mathrm{pK}_{\mathrm{BH}}{ }^{+}=23.6$

$\$ 1.20 / \mathrm{mmol}$<smiles>C1CCC2=NCCCN2CC1</smiles>

DBU (B4)

$\mathrm{pK}_{\mathrm{BH}}{ }^{+}=24.3$

$\$ 0.03 / \mathrm{mmol}$

Table S1<smiles></smiles>

BTTP (B6) $\mathrm{pK}_{\mathrm{BH}}{ }^{+}=28.4$<smiles>CCN=P(N(C)C)(N(C)C)N(C)[PH](C)(C)N</smiles>

$\mathrm{P}_{2} \mathrm{Et}$ (B7)

$\mathrm{pK}_{\mathrm{BH}}{ }^{+}=32.9$

$\$ 40.00 / \mathrm{mmol}$

\begin{tabular}{|c|c|c|c|c|c|}
\hline $\begin{array}{c}\text { Base } \\
\text { Number }\end{array}$ & $\begin{array}{c}\text { Base } \\
\text { Abbreviation }\end{array}$ & MW (g/mol) & CAS Number & Supplier & $\begin{array}{c}\text { Density } \\
\text { (g/mL) }\end{array}$ \\
\hline B1 & TEA & 101.19 & $121-44-8$ & Millipore-Sigma & 0.726 \\
\hline B2 & TMG & 115.18 & $80-70-6$ & BetaPharma & 0.918 \\
\hline B3 & BTMG & 171.28 & $29166-72-1$ & BetaPharma & 0.85 \\
\hline B4 & DBU & 152.24 & $6674-22-2$ & ChemShuttle & 1.018 \\
\hline B5 & MTBD & 153.22 & $84030-20-6$ & Enamine BB & 1.067 \\
\hline B6 & BTTP & 312.43 & $161118-67-8$ & Millipore-Sigma & 1.022 \\
\hline B7 & P2Et & 339.4 & $165535-45-5$ & Millipore-Sigma & 1.02 \\
\hline
\end{tabular}

\begin{tabular}{|c|c|c|c|c|c|}
\hline Base & $\begin{array}{c}\text { Volume } \\
\text { Available }(\mathbf{m L})\end{array}$ & $\begin{array}{c}\text { Mass } \\
\text { Available } \mathbf{( g )}\end{array}$ & $\mathbf{m m o l}$ & Price & Price/mmol \\
\hline TEA & 20000.00 & 14520 & 143492.4 & $\$ 1,830.00$ & $\$ 0.01$ \\
\hline TMG & 21786.49 & 20000 & 173641.3 & $\$ 184.00$ & $\$ 0.001$ \\
\hline BTMG & 117.65 & 100 & 583.8 & $\$ 706.00$ & $\$ 1.21$ \\
\hline DBU & 4911.59 & 5000 & 32842.9 & $\$ 893.00$ & $\$ 0.03$ \\
\hline MTBD & 9.37 & 10 & 65.3 & $\$ 511.00$ & $\$ 7.83$ \\
\hline BTTP & 25.00 & 25.55 & 81.8 & $\$ 572.00$ & $\$ 6.99$ \\
\hline P2Et & 5.00 & 5.1 & 15.0 & $\$ 601.00$ & $\$ 40.00$ \\
\hline
\end{tabular}




\section{Preparation of Starting Materials and Product Standards}<smiles>CCCOc1ccc(C)cc1</smiles>

S1<smiles>Cc1ccc(Nc2ccccc2)cc1</smiles>

S2<smiles>Cc1ccc(NC(=O)c2ccccc2)cc1</smiles>

S3<smiles>Cc1ccc(NCCc2ccccc2)cc1</smiles>

S4<smiles>Cc1ccc(N2CCOCC2)cc1</smiles>

S5

Starting material $\mathbf{S 1}{ }^{1}$ was prepared according to the literature procedure.

Authentic standard for product S2 was purchased from Alfa Aesar (Product Number: 44560). Standards for products $\mathbf{S 3},{ }^{2} \mathbf{S 4},{ }^{3}$ and $\mathbf{S 5}^{3}$ were prepared according to literature procedures. Products $\mathbf{S 2},{ }^{4} \mathbf{S 3},{ }^{5} \mathbf{S 4},{ }^{6}$ and $\mathbf{S 5},{ }^{7}$ have previously been reported and characterized. 


\section{Preparation of Precatalysts}

The general procedure for preparing oxidative addition precatalysts was adapted from our previous disclosures in which analogous complexes were reported. ${ }^{8}$
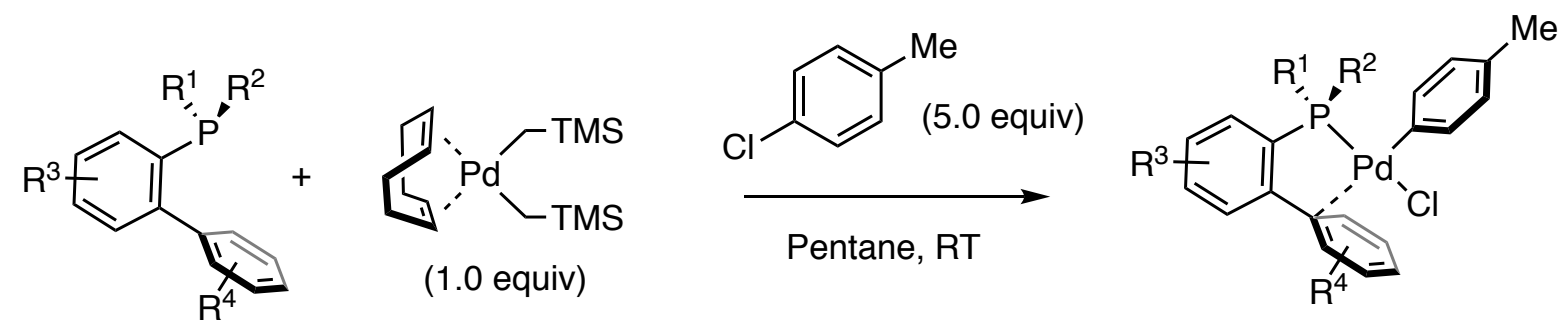

An oven-dried reaction tube (Fisher $16 \times 125 \mathrm{~mm}$ tubes - Cat. No. 1495935A) equipped with a stir bar was charged with the desired dialkyl arylphosphine ligand (1.0 equiv). The reaction tube was brought into a nitrogen-filled glovebox and was sequentially charged with 4-chlorotoluene (5.0 equiv) and pentane (a minimal amount of pentane $(\sim 3-8 \mathrm{~mL})$ to dissolve the ligand). The solution was vigorously stirred to ensure the ligand was completely dissolved. $\mathrm{COD}\left(\mathrm{Pd}\left(\mathrm{CH}_{2} \mathrm{TMS}\right)_{2}\right)\left(1.0\right.$ equiv, prepared as previously reported $\left.{ }^{9}\right)$ was added to the reaction tube in one portion, which resulted in an immediate color change of the solution from colorless to light yellow. Pentane $(0.25 \mathrm{~mL})$ was used to wash the walls of the reaction tube. The mixture was capped with a screw cap (Kimble Chase, Open Top S/T, Part No. 73804-15425) that was fitted with a Teflon septum (Thermo Scientific, 10/90 Teflon/Sil, Cat. No. B7995-15) and the solution was stirred in the glovebox for $12 \mathrm{~h}$ to give a yellow or white suspension. The solid that had formed was filtered (in the glovebox) and was washed with pentane $(4 \times 15 \mathrm{~mL})$ to afford the oxidative addition complex (P1-3, P7) as a powder. These oxidative addition complexes were then used without further purification and were stored in a desiccator on the benchtop, outside of the glovebox. Under these conditions, the precatalysts were stable for at least 12 months. 


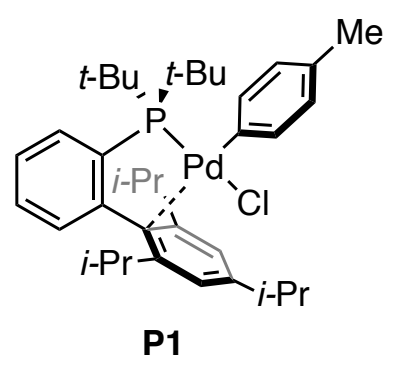

\section{t-BuXPhos (L1) Supported Oxidative Addition Complex, P1}

The general procedure was followed on a $1.00 \mathrm{mmol}$ scale using $t$-BuXPhos (425 mg, $1.00 \mathrm{mmol}), \mathrm{COD}\left(\mathrm{Pd}\left(\mathrm{CH}_{2} \mathrm{TMS}\right)_{2}\right)$ (389 mg, $\left.1.00 \mathrm{mmol}\right)$, and $p$ tolyl chloride $(490 \mu \mathrm{L}, 5.0 \mathrm{mmol})$ to afford $\mathbf{P 1}$ as a white powder $(473 \mathrm{mg}$, $72 \%$ yield). ${ }^{1} \mathbf{H}$ NMR $\left(400 \mathrm{MHz} ; \mathrm{CDCl}_{3}\right): \delta \mathrm{ppm} 7.97(\mathrm{td}, J=5.9,3.0 \mathrm{~Hz}$, $1 \mathrm{H}), 7.37(\mathrm{dd}, J=5.9,3.4 \mathrm{~Hz}, 2 \mathrm{H}), 7.07(\mathrm{~s}, 2 \mathrm{H}), 6.95(\mathrm{~d}, J=6.8 \mathrm{~Hz}, 2 \mathrm{H}), 6.82(\mathrm{dt}, J=6.6,3.5 \mathrm{~Hz}$, $1 \mathrm{H}), 6.65$ (d, $J=7.9 \mathrm{~Hz}, 2 \mathrm{H}), 3.01$ (hept, $J=6.9 \mathrm{~Hz}, 1 \mathrm{H}$ ), 2.53 (hept, $J=6.6 \mathrm{~Hz}, 2 \mathrm{H}$ ), 2.14 (s, $3 \mathrm{H}), 1.57(\mathrm{~d}, J=6.8 \mathrm{~Hz}, 6 \mathrm{H}), 1.48-1.30(\mathrm{~m}, 25 \mathrm{H}), 0.90(\mathrm{~d}, J=6.6 \mathrm{~Hz}, 6 \mathrm{H}) .{ }^{13} \mathbf{C}$ NMR $(101$ $\left.\mathrm{MHz} ; \mathrm{CDCl}_{3}\right): \delta$ ppm 157.06, 151.58, $147.82(\mathrm{~d}, J=19.1 \mathrm{~Hz}), 137.71(\mathrm{~d}, J=2.8 \mathrm{~Hz}), 137.00$, 136.78, 136.53, 135.23, 134.62, 134.48 (d, $J=10.4 \mathrm{~Hz}), 131.88,130.13$ (d, $J=1.8 \mathrm{~Hz}), 129.90$ $(\mathrm{d}, J=2.2 \mathrm{~Hz}), 129.57,127.65,126.76(\mathrm{~d}, J=4.1 \mathrm{~Hz}), 125.65(\mathrm{~d}, J=4.6 \mathrm{~Hz}), 125.04(\mathrm{~d}, J=3.5$ Hz), 124.66, 39.28 (d, $J=15.6 \mathrm{~Hz}), 34.62,32.28,32.26,32.22,31.73$ (d, $J=4.9 \mathrm{~Hz}), 31.40,29.55$ (d, $J=4.7 \mathrm{~Hz}), 25.68,24.74$ (d, $J=10.4 \mathrm{~Hz}), 24.69,21.11$ (d, $J=14.1 \mathrm{~Hz}), 20.53$.

${ }^{31} \mathbf{P}$ NMR (162 MHz; $\left.\mathrm{CDCl}_{3}\right): \delta$ ppm 66.6, 51.9. IR (neat, $\mathrm{cm}^{-1}$ ): 2962.1, 2929.2, 2864.3, 1477.1, 1169.6, 1010.0, 781.2. MP:178.3-181. ${ }^{\circ} \mathrm{C}$ (decomposition). HRMS: $\mathrm{m} / \mathrm{z}$ calcd. for $\mathrm{C}_{36} \mathrm{H}_{52} \mathrm{PPd}$ $[\mathrm{M}-\mathrm{Cl}]^{+} 621.2841$, found $621.2844 \mathrm{~m} / \mathrm{z}$.

\section{t-BuBrettPhos (L2) Supported Oxidative Addition Complex, P2}

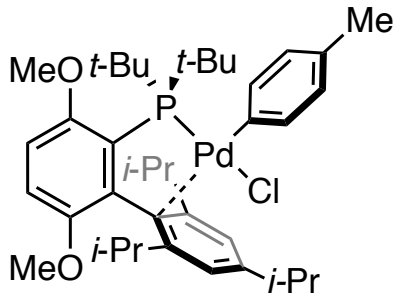

P2

The general procedure was followed on a $0.75 \mathrm{mmol}$ scale using $t$ BuBrettPhos (487 mg, $0.75 \mathrm{mmol}), \mathrm{COD}\left(\mathrm{Pd}\left(\mathrm{CH}_{2} \mathrm{TMS}\right)_{2}\right)(292 \mathrm{mg}, 0.75$ mmol), and $p$-tolyl chloride (440 $\mu \mathrm{L}, 3.75 \mathrm{mmol})$ to afford $\mathbf{P 2}$ as a bright yellow powder ( $\mathrm{mg}, 79 \%$ yield). ${ }^{1} \mathbf{H}$ NMR (400 MHz; $\left.\mathrm{CDCl}_{3}\right): \delta \mathrm{ppm} \delta$ $8.88(\mathrm{~d}, J=8.0 \mathrm{~Hz}, 1 \mathrm{H}), 7.51(\mathrm{q}, J=7.8 \mathrm{~Hz}, 4 \mathrm{H}), 7.36-7.00(\mathrm{~m}, 7 \mathrm{H})$, $6.87(\mathrm{~d}, J=7.8 \mathrm{~Hz}, 1 \mathrm{H}), 6.10(\mathrm{~s}, 1 \mathrm{H}), 4.14-3.90(\mathrm{~m}, 9 \mathrm{H}), 3.59(\mathrm{~s}, 1 \mathrm{H}), 3.40(\mathrm{~d}, J=38.9 \mathrm{~Hz}, 1 \mathrm{H})$, $3.23(\mathrm{p}, J=6.9 \mathrm{~Hz}, 1 \mathrm{H}), 2.82$ (p, J=6.8 Hz, 1H), 2.56 (s, 5H), 2.39 (s, 2H), 2.25 (h, $J=6.6 \mathrm{~Hz}$, 1H), $1.93-1.54(\mathrm{~m}, 41 \mathrm{H}), 1.39(\mathrm{ddd}, J=35.2,24.9,6.8 \mathrm{~Hz}, 17 \mathrm{H}), 1.07$ (d, $J=6.6 \mathrm{~Hz}, 3 \mathrm{H}), 0.97$ $(\mathrm{d}, J=6.5 \mathrm{~Hz}, 4 \mathrm{H}), 0.26(\mathrm{~d}, J=7.1 \mathrm{~Hz}, 4 \mathrm{H}) .{ }^{13} \mathbf{C} \mathbf{N M R}\left(101 \mathrm{MHz} ; \mathrm{CDCl}_{3}\right): \delta \mathrm{ppm} 175.06(\mathrm{~d}, J=$ 8.6 Hz), 154.88, 153.52, 151.44, 138.62, 136.82, 135.86, 135.65, 131.17, 131.14, 130.02, 128.24, $127.13,124.52,113.47,109.96(\mathrm{~d}, J=3.7 \mathrm{~Hz}), 97.79,54.88,54.54,54.25,53.86,51.88(\mathrm{~d}, J=8.3$ Hz), 40.78, 40.19, 40.06, 39.29 (d, $J=7.6 \mathrm{~Hz}), 33.59,32.88,32.66$ (d, $J=5.9 \mathrm{~Hz}), 32.53,31.37$, 
30.40 (d, $J=5.4 \mathrm{~Hz}), 25.81,24.78(\mathrm{~d}, J=5.5 \mathrm{~Hz}), 22.87$ (d, $J=4.5 \mathrm{~Hz}), 22.48$ (d, $J=4.2 \mathrm{~Hz})$, 22.37, 22.34, $21.30(\mathrm{~d}, J=6.6 \mathrm{~Hz}), 21.22,20.73,20.54,20.17(\mathrm{~d}, J=4.6 \mathrm{~Hz}) .{ }^{31} \mathbf{P}$ NMR $(162$ $\mathrm{MHz} ; \mathrm{CDCl}_{3}$ ): $\delta$ (ppm) 79.7, 71.8. IR (neat, $\mathrm{cm}^{-1}$ ): 2969.1, 2864.9, 1579.2, 1421.9, 1266.6, 1046.5, 797. MP: $164.3-167.8{ }^{\circ} \mathrm{C}$ (decomposition). HRMS: $\mathrm{m} / \mathrm{z}$ calcd. for for $\mathrm{C}_{38} \mathrm{H}_{56} \mathrm{O}_{2} \mathrm{PPd}[\mathrm{M}-\mathrm{Cl}]^{+}$ 681.3053. Found: 681.305.

\section{AlPhos (L3) Supported Oxidative Addition Complex, P3}

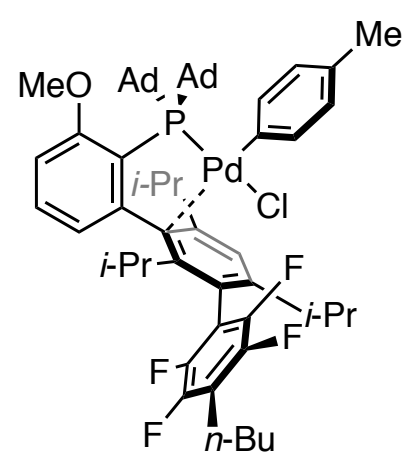

The general procedure was followed on a $0.37 \mathrm{mmol}$ scale using AlPhos (300 mg, $0.37 \mathrm{mmol}), \mathrm{COD}\left(\mathrm{Pd}\left(\mathrm{CH}_{2} \mathrm{TMS}\right)_{2}\right)$ (144 mg, $\left.0.37 \mathrm{mmol}\right)$, and p-tolyl chloride $(220 \mu \mathrm{L}, 1.85 \mathrm{mmol})$ to affordP3 as a pale yellow powder (167 mg, 43\% yield). ${ }^{1} \mathbf{H}$ NMR (400 MHz; $\left.\mathrm{CDCl}_{3}\right): \delta$ ppm 7.34 (t, $J=7.9 \mathrm{~Hz}, 1 \mathrm{H}), 7.27(\mathrm{~s}, 1 \mathrm{H}), 7.12-6.97$ (m, 2H), 6.90 (d, $J=8.2$ $\mathrm{Hz}, 1 \mathrm{H}), 6.66$ (d, $J=8.3 \mathrm{~Hz}, 2 \mathrm{H}), 6.41(\mathrm{dd}, J=7.5,2.7 \mathrm{~Hz}, 1 \mathrm{H}), 3.90$ (s, 3H), 3.20 (p, $J=7.1 \mathrm{~Hz}, 1 \mathrm{H}), 2.80(\mathrm{t}, J=7.7 \mathrm{~Hz}, 2 \mathrm{H}), 2.44$ (q, $J=$ $13.0 \mathrm{~Hz}, 6 \mathrm{H}), 2.36-2.23(\mathrm{~m}, 2 \mathrm{H}), 2.13(\mathrm{~d}, J=22.3 \mathrm{~Hz}, 6 \mathrm{H}), 2.03(\mathrm{~s}, 4 \mathrm{H}), 1.92-1.76(\mathrm{~m}, 9 \mathrm{H})$, $1.68(\mathrm{dt}, J=21.2,12.6 \mathrm{~Hz}, 12 \mathrm{H}), 1.53(\mathrm{~d}, J=12.3 \mathrm{~Hz}, 3 \mathrm{H}), 1.42(\mathrm{~h}, J=7.2 \mathrm{~Hz}, 2 \mathrm{H}), 1.32(\mathrm{~d}, J=$ $6.8 \mathrm{~Hz}, 3 \mathrm{H}), 1.25(\mathrm{~d}, J=7.0 \mathrm{~Hz}, 3 \mathrm{H}), 1.11(\mathrm{~d}, J=6.8 \mathrm{~Hz}, 3 \mathrm{H}), 0.97$ (t, $J=7.4 \mathrm{~Hz}, 3 \mathrm{H}), 0.86(\mathrm{~d}, J$

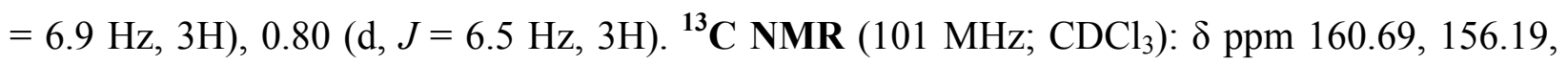
$151.16,150.65,150.47,149.91,138.84,136.50,132.74,132.67,131.39,131.20,128.05,127.96$, $127.89,127.57,127.45,127.40,127.25,126.04,109.09,53.78,46.87$ (d, $J=11.4 \mathrm{~Hz}), 45.86$ (d, $J$ $=10.5 \mathrm{~Hz}), 42.52,40.04,36.52,36.19,33.10,31.50,31.05$ (d, $J=14.5 \mathrm{~Hz}), 29.43$ (dd, $J=25.2$, 9.4 Hz), 25.91, 25.41, 25.01, 24.22, 23.63, 22.75, 22.41, 22.29, 20.39, 13.81. ${ }^{31}$ P NMR (162 MHz; $\left.\mathrm{CDCl}_{3}\right): \delta(\mathrm{ppm})$ 68.2. ${ }^{19} \mathbf{F}$ NMR $\left(376 \mathrm{MHz} ; \mathrm{CDCl}_{3}\right) \delta-130.19(\mathrm{dd}, J=23.8,12.6 \mathrm{~Hz}),-137.38$ $(\mathrm{dd}, J=24.3,12.1 \mathrm{~Hz}),-144.87(\mathrm{dd}, J=23.8,12.2 \mathrm{~Hz}),-146.59$ (dd, $J=24.1,12.8 \mathrm{~Hz}) . \mathbf{I R}$ (neat, $\mathrm{cm}^{-1}$ ): 2905.7, 28450, 1566.4, 1475.6, 1007.7, 977.4, 791.7. MP: 181.2-183.4 ${ }^{\circ} \mathrm{C}$ (decomposition). HRMS: $\mathrm{m} / \mathrm{z}$ calcd. for $\mathrm{C}_{59} \mathrm{H}_{74} \mathrm{~F}_{4} \mathrm{OPPd}[\mathrm{M}-\mathrm{Cl}]^{+} 1011.4448$. Found: $1011.4463 \mathrm{~m} / \mathrm{z}$. 


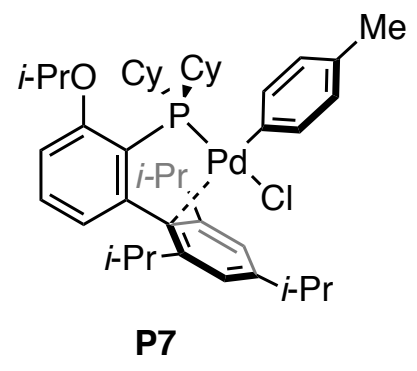

EPhos (L7) Supported Oxidative Addition Complex, P7

The general procedure was followed on a $0.52 \mathrm{mmol}$ scale using EPhos (280 mg, $0.52 \mathrm{mmol}), \mathrm{COD}\left(\mathrm{Pd}\left(\mathrm{CH}_{2} \mathrm{TMS}\right)_{2}\right)(204 \mathrm{mg}, 0.52 \mathrm{mmol})$, and $p$-tolyl chloride ( $215 \mu \mathrm{L}, 2.6 \mathrm{mmol}$ ) to afford $\mathbf{P 7}$ as a white powder (261 $\mathrm{mg}, 65 \%$ yield). ${ }^{1} \mathbf{H}$ NMR (400 MHz; $\left.\mathrm{CDCl}_{3}\right): \delta$ ppm $7.28-7.24(\mathrm{~m}$, 1H), $7.06(\mathrm{~s}, 2 \mathrm{H}), 6.91(\mathrm{~d}, J=7.7 \mathrm{~Hz}, 2 \mathrm{H}), 6.80(\mathrm{~d}, J=8.3 \mathrm{~Hz}, 1 \mathrm{H}), 6.69$ (d, $J=7.7 \mathrm{~Hz}, 2 \mathrm{H}), 6.29$ (d, $J=7.6 \mathrm{~Hz}, 1 \mathrm{H}), 4.75$ (h, $J=6.1 \mathrm{~Hz}, 1 \mathrm{H}), 3.12-2.80$ (m, 3H), 2.52 (h, $J=6.9 \mathrm{~Hz}, 2 \mathrm{H}), 2.16$ (m, 2H), 1.87, $1.76,1.66-1.59$ (m, 17H), 1.45 (d, $J=6.0 \mathrm{~Hz}, 6 \mathrm{H}), 1.36$ $(\mathrm{d}, J=6.9 \mathrm{~Hz}, 6 \mathrm{H}), 1.17$ (m, $6 \mathrm{H}) 0.90$ (m, 8H). ${ }^{13} \mathbf{C}$ NMR (101 MHz; $\left.\mathrm{CDCl}_{3}\right): \delta$ ppm 159.81, 159.78, 156.44, 156.44, 150.52 (d, $J=19.3 \mathrm{~Hz}), 149.83,136.69$ (d, $J=3.0 \mathrm{~Hz}), 134.50,132.10$, 131.51, 127.94, 126.21 (d, $J=11.2 \mathrm{~Hz}), 124.51,123.64,122.68,122.42,110.30,110.27,70.07$, 35.00, 34.65 (d, $J=15.0 \mathrm{~Hz}), 31.58,29.14$ (d, $J=2.1 \mathrm{~Hz}), 29.13,27.80$ (dd, $J=20.8,12.6 \mathrm{~Hz}$ ), 26.20, 25.75, 24.84 (d, $J=4.9 \mathrm{~Hz}), 21.97,20.72 .{ }^{31} \mathbf{P}$ NMR (162 MHz; $\left.\mathrm{CDCl}_{3}\right): \delta$ ppm 38.2. IR $\left(\right.$ neat, $\left.\mathrm{cm}^{-1}\right): 2958.6,2920.0,2850.3,1567.0,1258.1,1103.7,955.9$. MP: $170.3-174.1{ }^{\circ} \mathrm{C}$ (decomposition). HRMS: $\mathrm{m} / \mathrm{z}$ calcd. for $\mathrm{C}_{42} \mathrm{H}_{62} \mathrm{OPPd}[\mathrm{M}-\mathrm{Cl}]^{+}$731.3573. Found: $731.3605 \mathrm{~m} / \mathrm{z}$. 


\section{General Procedure for Reaction Screening}

The general procedure for reaction screening was adapted from our previous work preparing analogous complexes. ${ }^{8}$ In this study, new bases were screened for their ability to facilitate the reaction.

All reactions were carried out in a nitrogen-filled glovebox. In all reactions, stock solutions of reagents in tetrahydrofuran (THF) were used. In cases where reagents were only partially soluble, additions of a slurry of the material in THF were employed. A THF solution $(50 \mu \mathrm{L})$ containing an oxidative addition complex $(0.010 \mathrm{mmol})$ and hexamethyl benzene (internal standard, 0.0050 $\mathrm{mmol})$ was transferred to an oven-dried vial $(2.0 \mathrm{~mL})$ equipped with a stir bar. The desired amine nucleophile $(0.015 \mathrm{mmol})$ was added to the vial via syringe (if a liquid) or as a solution in THF $(25 \mu \mathrm{L})$ (if a solid), followed by the base $(0.020 \mathrm{mmol})$ as a solution or neat. In all cases, the total volume of THF was $100 \mu \mathrm{L}(0.10 \mathrm{M})$. The reaction mixtures were allowed to stir for $16 \mathrm{~h}$ at roomtemperature. The reaction mixture was then diluted with EtOAc, filtered through a small plug of silica gel and analyzed via GC. Yields were based on a calibrated GC method and are reported as a single run. 

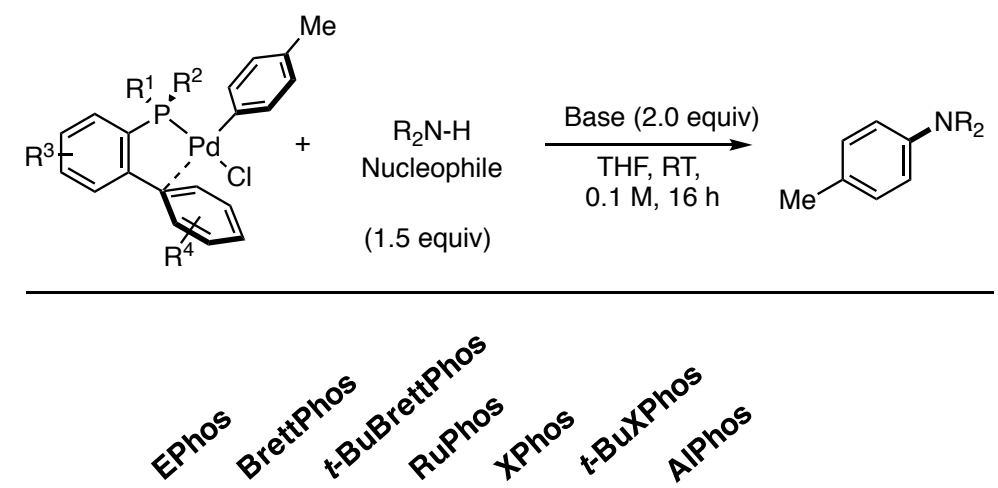

\begin{tabular}{|c|c|c|c|c|c|c|c|c|}
\hline$P_{2}$-Et & 99 & 99 & 75 & 82 & 86 & 99 & 75 & \multirow{4}{*}{ s2 } \\
\hline BTTP & 99 & 63 & 16 & 18 & 80 & 29 & 69 & \\
\hline$P_{1}-t-O c t$ & 99 & 15 & 16 & 0 & 10 & 13 & 57 & \\
\hline TBD & 87 & 53 & 81 & 0 & 0 & 62 & 96 & \\
\hline
\end{tabular}

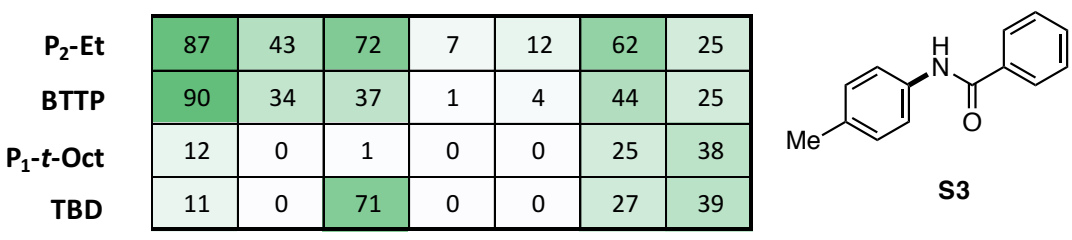

\begin{tabular}{|c|c|c|c|c|c|c|c|c|}
\hline$P_{2}$-Et & 56 & 81 & 60 & 11 & 14 & 86 & 29 & $\mathrm{H}$ \\
\hline BTTP & 1 & 0 & 0 & 0 & 0 & 9 & 8 & \\
\hline$P_{1}-t-O c t$ & 0 & 0 & 63 & 0 & 0 & 1 & 19 & S6 \\
\hline TBD & 1 & 0 & 0 & 0 & 0 & 1 & 57 & \\
\hline
\end{tabular}

\begin{tabular}{|c|c|c|c|c|c|c|c|}
\hline$P_{2}$-Et & 67 & 48 & 0 & 68 & 49 & 85 & 5 \\
\hline BTTP & 0 & 0 & 1 & 1 & 1 & 27 & 5 \\
\hline$P_{1}-t-O c t$ & 0 & 0 & 1 & 9 & 0 & 1 & 10 \\
\hline TBD & 0 & 0 & 0 & 0 & 0 & 1 & 3 \\
\hline
\end{tabular}<smiles>Cc1ccc(N2CCOCC2)cc1</smiles>

GC Yield (\%)

\begin{tabular}{lll}
\hline 0 & 50 & 100
\end{tabular}<smiles>CN1CCCN2CCCN=C12</smiles>

MTBD<smiles></smiles>

BTTP<smiles>COP(N)(=NC(C)(C)CC(C)(C)C)N(C)C</smiles>

$\mathrm{P}_{1}-\mathrm{t}$-Oct<smiles>CCN=P(N(C)C)(N(C)C)N(C)C</smiles>

$P_{2}$ Et

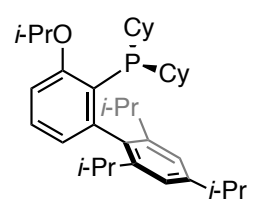

EPhos

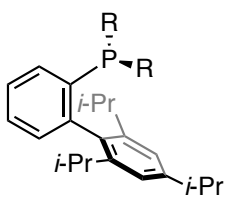

$\mathrm{R}=\mathrm{Cy}, \mathrm{XPhos}$ $\mathrm{R}=t$-Bu, $t$-BuXPhos

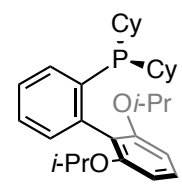

RuPhos

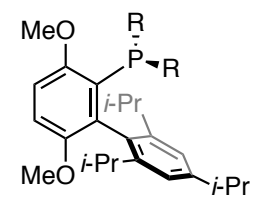

$\mathrm{R}=\mathrm{Cy}$, BrettPhos

$\mathrm{R}=t-\mathrm{Bu}, t-\mathrm{BuBret}$ Phos

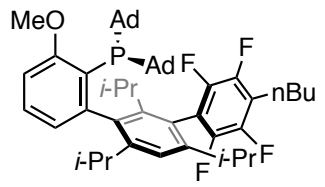

AlPhos 


\section{Use of the Microfluidic Optimization Platform}

\section{Optimization Algorithm}

The optimization algorithm used in this study has been described in detail. ${ }^{10}$ For this optimization campaign, the following changes were made:

The algorithm aimed to maximize objective function value $\phi(\mathrm{x}, \mathrm{y})=\log Y(\mathrm{x}, \mathrm{y})$ under variation of the discrete variables $\mathbf{y}$ and continuous variables $\mathbf{x}$. Therefore, the optimization objective can be formulated with (1).

$$
\max \phi(\mathrm{x}, \mathrm{y})=\max \log Y(\mathrm{x}, \mathrm{y})
$$

The main product yield $Y$ of the coupling reaction $\mathrm{A}+\mathrm{B} \rightarrow \mathrm{R}$ is calculated with (2) based on the initial concentration of the limiting component $C_{\mathrm{A}, 0}$ assuming a constant reaction volume. The resulting product concentration is $C_{\mathrm{R}}$.

$$
Y(\mathrm{x}, \mathrm{y})=\frac{C_{\mathrm{R}}}{C_{\mathrm{A}, 0}}
$$

We used the choice of $N_{\text {Bases }}$ mutually exclusive base type as discrete variables. They are represented by the one-hot vector $\mathbf{y}$ comprised of the components $y_{i} \in\{0,1\}$. For instance, if the reaction is performed with base type 1 out of a pool of $N_{\text {Bases }}=3$, the vector takes the form $\mathbf{y}=$ $\left[\begin{array}{lll}y_{1} & y_{2} & y_{3}\end{array}\right]=\left[\begin{array}{lll}1 & 0 & 0\end{array}\right]$. We considered three continuous variable $N_{\mathrm{cv}}=3$ for the optimization problem. The unscaled continuous variables were $\tilde{x}_{1}=\log \left(C_{\text {base }}\right), \tilde{x}_{2}=T^{-1}$, and $\tilde{x}_{3}=\log (t)$. Using the upper and lower limits of each variable defined by the user, the variables were scaled to the vector $\mathrm{x}$ with components $x_{j} \in[-1,+1]$.

The quadratic response surface model (3) was derived from a power law equation.

$$
\hat{b}=\sum_{i}^{N_{\mathrm{Bases}}} y_{i}\left(c_{i}+a_{i} x_{1}\right)+\sum_{j=2}^{N_{\mathrm{cv}}} a_{j}^{\prime} x_{j}+\sum_{j=1}^{N_{\mathrm{cv}}} \sum_{k=j}^{N_{\mathrm{cv}}} a_{j k} x_{j} x_{k}
$$

The model response value $\hat{b}=\log (Y)$ aims to describe the behavior of the reaction chemistry in 
dependence of the input variables $\mathbf{x}$ and $\mathbf{y}$. The behavior of each base $y_{i}$ out of the number of $N_{\text {Bases }}$ is described with a constant effect $c_{i}$ and a linear effect $a_{i}$ for the scaled base concentration $x_{1}$. The linear effects $a_{j}^{\prime}$ aim to describe the behavior of the scaled temperature $x_{2}$ and scaled reaction time $x_{3}$. The quadratic and interaction effects are $a_{j k}$. All model parameters were fitted for every iteration of the algorithm with the weighted least-squares regression described in the previous paper.

The D-optimal design of our optimization runs were generated from a 5-level full factorial design with the number of extra experiments set to $N_{\text {extra }}=3$. The other optimization parameters remained unchanged. 


\section{General Procedure for Online Optimization}

\section{Stock Solution Preparation}

Up to seven stock solutions were prepared for each of the 12 optimization runs. An overview with the resulting concentrations is presented in the attached Excel file. All solvents were degassed prior to use. To do this, a needle connected to a nitrogen-filled manifold was inserted into the septum of the solvent bottle. The needle tip was submerged below the solvent line and nitrogen gas was bubbled through the solvent. A needle connected to a vacuum pump was inserted into the septum of the bottle such that the needle tip remained in the head space of the bottle. The vacuum pump was used to remove gas from the head space of the bottle while the nitrogen gas was bubbled through the solvent. This degassing process was performed for $10 \mathrm{~min}$. After this time, the vacuum line was removed and bottle was refilled with nitrogen. Generally, chemicals were weighed (Sartorius MC21S Micro Balance, $0.001 \mathrm{mg}$ ) into volumetric flasks outside of a glovebox. The flasks were then brought into a glovebox and were sealed with caps containing a silicone rubber septum. For solutions prepared outside of a glovebox, the flask was sealed with a cap and the head space of the flask was purged with nitrogen using standard Schlenk techniques. Liquids were transferred between flasks and vials using syringes. After preparation, all stock solutions were transferred to $2 \mathrm{~mL}$ tapered vials with silicone rubber septum and stored in the vial rack of the liquid handler.

In a nitrogen-filled glovebox, a stock solution containing the desired precatalyst was prepared by charging a volumetric flask $(1.0 \mathrm{~mL})$ with the desired precatalyst (P1-P3). The flask was filled to the mark with solvent (2-methyl tetrahydrofuran (2-MeTHF) or dimethyl sulfoxide (DMSO)). A second volumetric flask $(10.0 \mathrm{~mL})$ was charged with $p$-tolyl triflate, 1-fluoronaphthalene (internal standard), and was filled to the mark with the desired solvent. A stir bar was added to the flask containing the precatalyst slurry. The mixture was vigorously stirred to afford a fine suspension of precatalyst in 2-MeTHF. While stirring, the stock solution mixtures were transferred to separate vials $(2.0 \mathrm{~mL}$, tapered) each equipped with a magnetic stir bar $(6 \mathrm{~mm})$. All slurry additions of the precatalyst solution took place while the mixture was vigorously stirring to ensure reproducible, uniform transfer of regularly distributed particles. ${ }^{11}$ The vials were sealed with a septum cap. Specific stock solution concentrations can be found in the Excel file of the Supporting Information. 
Individual stock solutions containing aniline, phenethylamine, or morpholine were prepared by charging a vial $(2.0 \mathrm{~mL}$, tapered) with the neat liquid amine. The vial was sealed with a septum cap and was pierced with a needle connected to a Schlenk line. The tube was evacuated and backfilled with nitrogen (this process was repeated a total of three times). In the case of benzamide, a screw-top volumetric flask $(2.0 \mathrm{~mL})$ was charged with amide $(1.053 \mathrm{~g}, 8.69 \mathrm{mmol})$ and was sealed with a screw-top fitted with a Teflon septum. The flask was evacuated and backfilled with nitrogen as previously described. Then DMSO was added to the flask via syringe until the flask was filled to the mark. The flask was sonicated to yield a homogenous solution with a benzamide concentration of $4.3 \mathrm{M}$.

The stock solutions containing the bases TEA, TMG, DBU, and MTBD were prepared by transferring the neat reagent to a vial $(2.0 \mathrm{~mL})$. The vial was sealed with a septum cap and was evacuated and backfilled with nitrogen as previously described. The stock solutions containing the bases BTMG and BTTP were prepared in an analogous way inside a nitrogen-filled glove box.

\section{Optimization System}

The online optimization system used in this study has been modified from our previous

optimization campaigns. ${ }^{10}$ An overview of the system is given in Figure S1. A flow diagram is depicted in Figure S2. The startup and operation of the system remained unchanged and have been previously described in detail. ${ }^{10}$ 


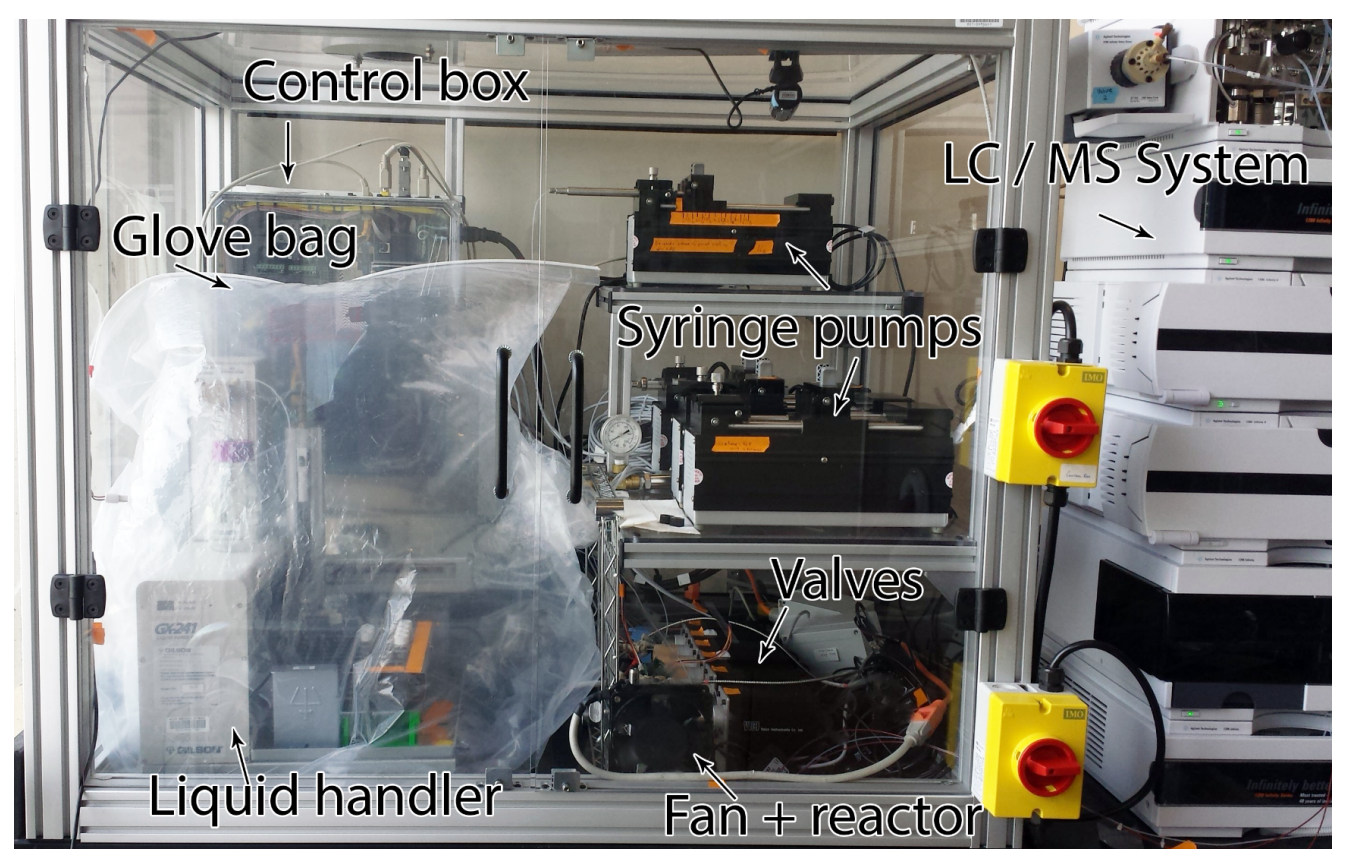

Figure S1: Optimization system overview.

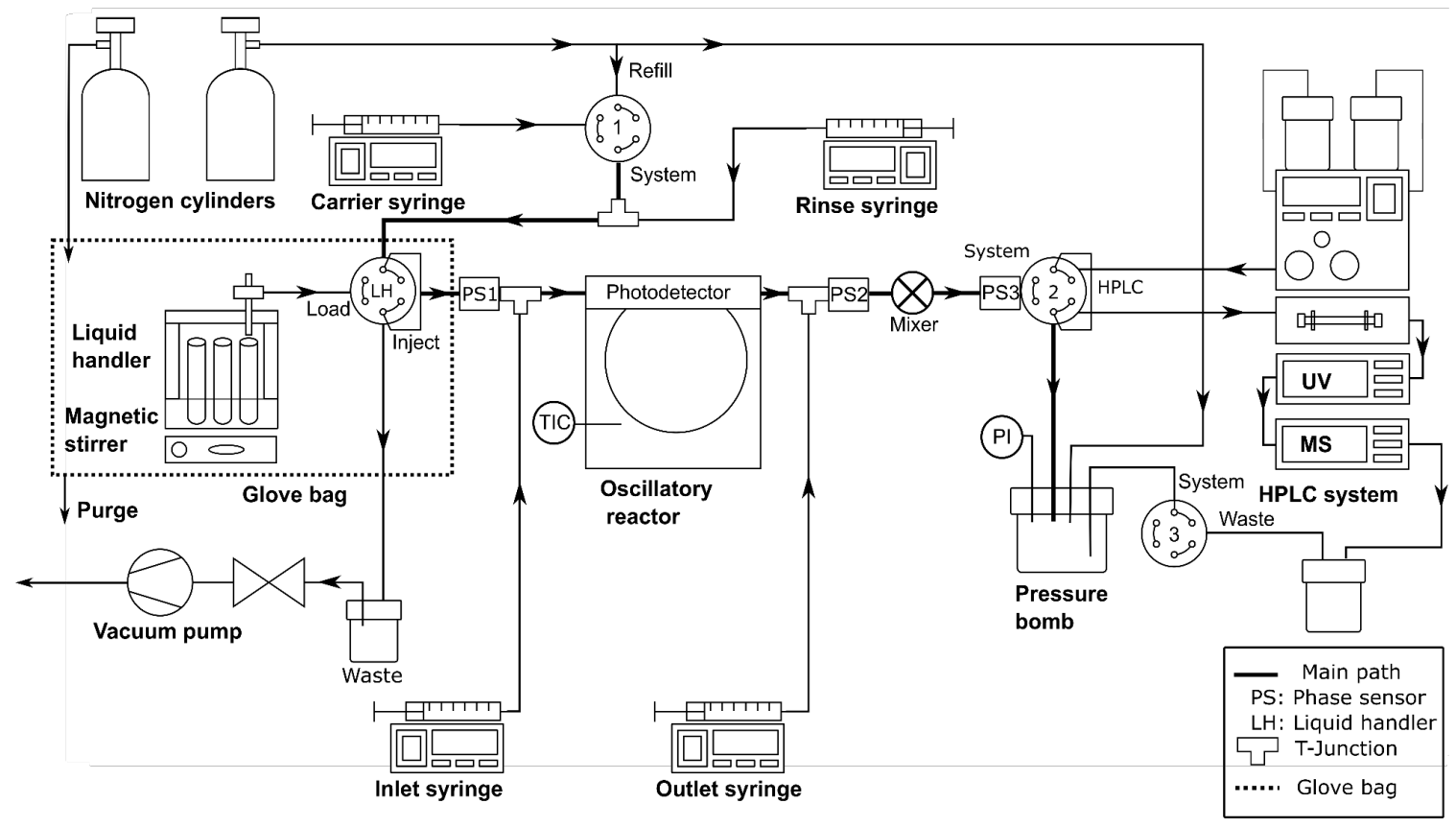

Figure S2: Optimization system flow chart. 
The optimization platform incorporated a polyethylene glove bag (Atmosbag, Sigma-Aldrich) filled with a dry, high purity nitrogen atmosphere (Figure S1). The bag contained the liquid handler, the vial rack, and the injection module with the 6-port-2-position valve (Figure S2). Cable and tubing connections running through the glove bag were sealed with silicone glue and tape.

After the vials containing the stock solutions were prepared, they were transferred to the vial rack of the liquid handler. The bag was sealed and purged with dry nitrogen from a standard gas cylinder. A slight positive pressure of nitrogen inside the bag was maintained by continuously introducing nitrogen into the bag $\left(100 \mathrm{~mL} \mathrm{~min}^{-1}\right)$. An oxygen monitor (GasAlert Quattro, Honeywell) was used to ensure the oxygen concentration remained at $0.1 \%$ or lower during the optimization run.

The stock solution containing the desired precatalyst was placed on top of a magnetic stirrer housed under the vial rack (Figure S3). The solutions were stirred vigorously to ensure that the fine suspension was well mixed in during the course of the optimization run. The depth to which the liquid handler lowered the sample probe into the vial was fixed to ensure robust withdrawal of liquid without interfering with the stir bar.

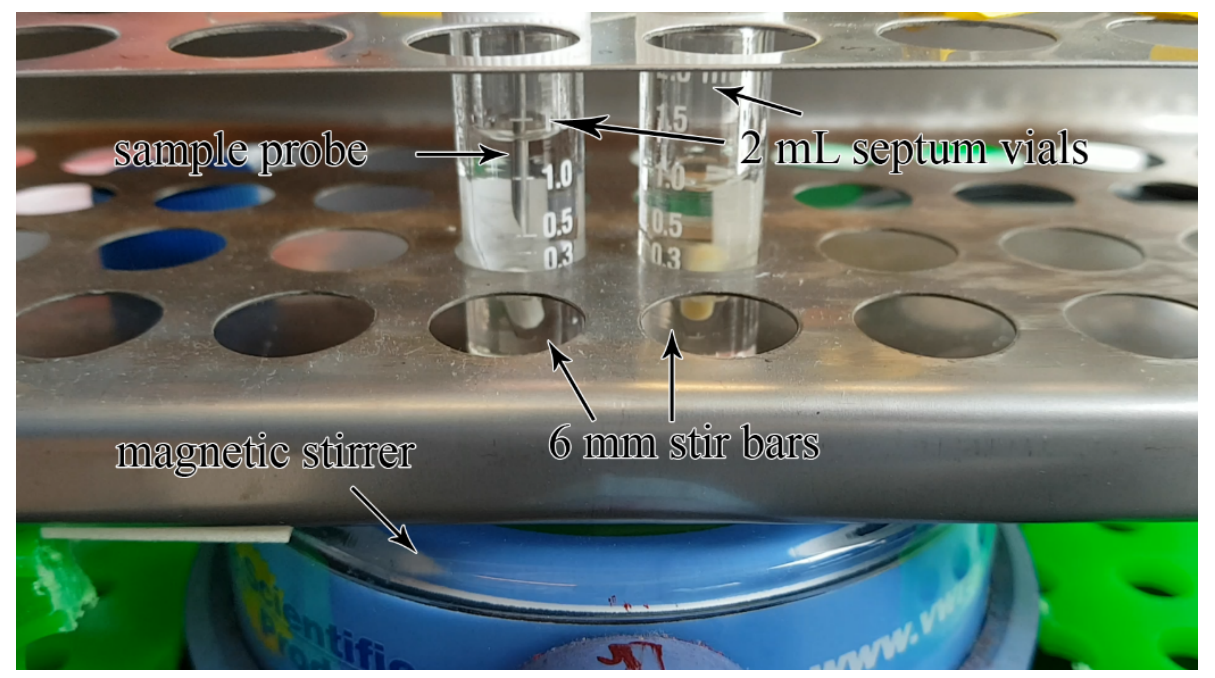

Figure S3: Liquid handler vial rack with integrated magnetic stirrer. 
Following the placement of the stock solutions in the vial rack of the liquid handler, the optimization system was then started by the user. ${ }^{10}$ The droplet was heated in a reactor loop for the designated time at a specified temperature and then was diluted by the reaction solvent in-line. The system then carried out the sampling from the quenched reaction droplet with a second 6-port2-position valve (Figure S4).
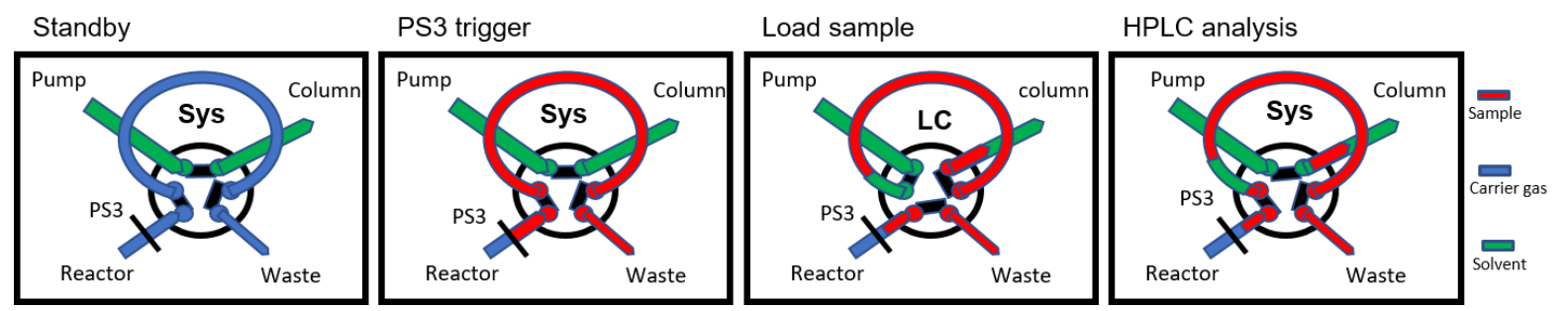

Figure S4: Online sampling from the reaction system to the LC/MS system. Sys: System position. LC: LC position.

When there was no sample to transfer to the LC/MS, the sample loop was connected to the reaction system (system position). The tubing lines of the system were filled with the carrier gas. A HPLC pump provided a steady standby flow rate of $0.1 \mathrm{~mL} \mathrm{~min}^{-1}$. While the sample was pushed through the reactor loop, a phase sensor (PS3) at the inlet of the sample loop registered that the sample had passed through the loop after detecting gas again. To load a sample for LC/MS sampling, the valve was switched to the LC position connecting the sample loop with the LC/MS flow path. The valve was then switched back to the system position after a sampling time of $300 \mathrm{~ms}$. This process transferred $\sim 0.4 \mu \mathrm{L}$ of sample from the $1.7 \mu \mathrm{L}$ sample loop to the LC/MS flow path. The HPLC analysis method was then started. Any remaining sample was delivered to the waste container. 


\section{Data Analysis}

The online analysis was carried out with an LC/MS system (1260 Infinity, Agilent) equipped with a reverse-phase column (Eclipse Plus C8 RRHT 4.6 x 50mm, $1.8 \mu \mathrm{m}$ ). Mobile phases were comprised of water (HPLC Grade, Sigma-Aldirch) with $0.1 \mathrm{vol} \%$ trifluoroacetic acid (TFA) as aqueous solvent (A) and acetonitrile (HPLC Grade, Sigma-Aldirch) with 0.1 vol\% trifluoroacetic $\operatorname{acid}(\mathrm{TFA})(\mathrm{B})$.

Detailed information about the preparation of calibration standards, the chromatographic methods, and the calibration data is included in the attached Excel file. Table $\mathbf{S 2}$ explains which calibration curves were used for each specific online optimization. Further, the calibration parameter $C_{\text {cal }}$ (the inverse of the calibration curve slope) and the coefficient of determination $R^{2}$ are listed.

Table S2: Calibration curve summary for online optimization runs. Calibration parameter $C_{c a l}$ equals the inverse slope. Coefficient of determination $R^{2}$ describes the accuracy of the calibration curve.

\begin{tabular}{|l|l|l|l|}
\hline Optimization run & Curve number & \multicolumn{1}{|c|}{$C_{\text {cal }}$} & $\mathrm{R}^{2}$ \\
\hline- & - & $\mathrm{M}$ L/g ISTD & - \\
\hline Aniline - EPhos & 1 & 0.0324 & 1.00 \\
\hline Aniline $-t$-BuXPhos & 2 & 0.0309 & 0.99 \\
\hline Aniline - $t$-BuBrettPhos & 2 & 0.0309 & 0.99 \\
\hline Aniline - AlPhos & 2 & 0.0309 & 0.99 \\
\hline Benzamide $-t$-BuXPhos & 3 & 0.0715 & 0.99 \\
\hline Benzamide $-t$-BuBrettPhos & 4 & 0.0746 & 0.99 \\
\hline Benzamide - AlPhos & 3 & 0.0715 & 0.99 \\
\hline Phenethylamine $-t$-BuXPhos & 5 & 0.0601 & 0.99 \\
\hline Phenethylamine $-t$-BuBrettPhos & 6 & 0.0598 & 1.00 \\
\hline Phenethylamine - AlPhos & 6 & 0.0598 & 1.00 \\
\hline Morpholine $-t$-BuBrettPhos & 7 & 0.0822 & 0.99 \\
\hline Morpholine - AlPhos & 7 & 0.0822 & 0.99 \\
\hline Morpholine (Preliminary) $-t$-BuBrettPhos & 8 & 0.0764 & 0.99 \\
\hline$p$-tolyl triflate - all runs & 9 & 0.0693 & 1.00 \\
\hline
\end{tabular}


Equation (4) was used to calculate the product concentration for the online optimization runs.

$$
C_{\mathrm{R}}=C_{\text {cal }} \cdot \frac{A_{\mathrm{R}}}{A_{\mathrm{ISTD}}} \cdot C_{\mathrm{ISTD}}
$$

The internal standard concentration $C_{\mathrm{ISTD}}$ in $\mathrm{g} \mathrm{L}^{-1}$ was known from the droplet preparation. The product peak area $A_{\mathrm{R}}$ and $A_{\mathrm{ISTD}}$ was determined by the LC/MS software. A Matlab script was used to match the peak areas for certain wavelength and retention time window. The data detailed are included in the attached Excel document.

The reaction yield $Y$ was calculated with (2) using the product concentration $C_{\mathrm{R}}$ determined with (4). The nominal initial concentration of the limiting component $C_{\mathrm{A}, 0}^{*}$ ( $p$-tolyl triflate) calculated during the droplet preparation deviated from the concentrations determined with the HPLC system. We attribute this phenomenon to the compressibility of the gas buffer (Figure S5).

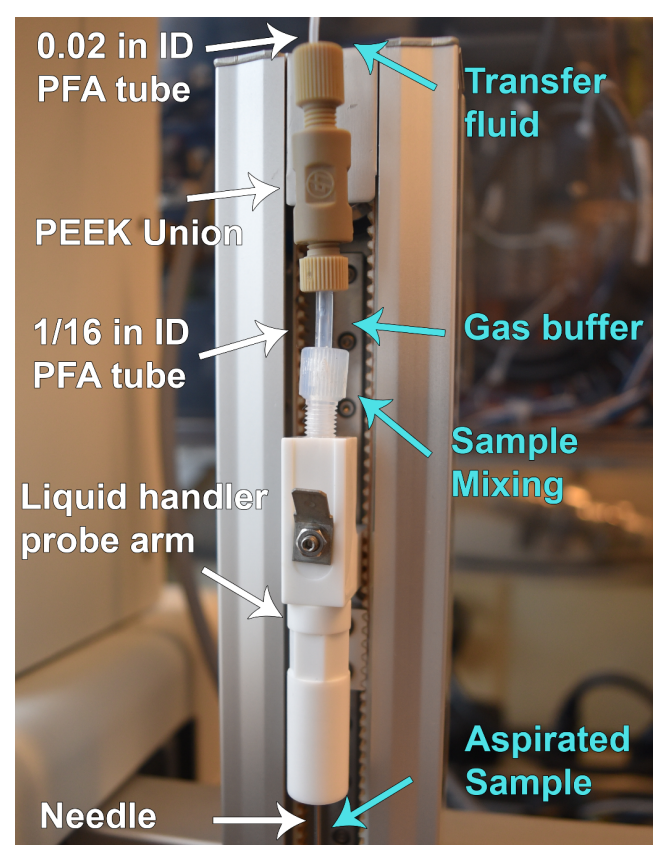

Figure S5: Liquid handler arm. The transfer fluid is separated by an inert gas buffer from the aspirated samples. 
This buffer separated the transfer fluid of the liquid handler and the aspirated liquid sample. To aspirate a certain volume of sample from a vial, the piston of the syringe pump was displaced by the same volume. This displacement was transferred through the incompressible transfer fluid (2MeTHF or DMSO) inside the tubing connecting the liquid handler syringe pump and the liquid handler arm. However, the compressibility of the gas buffer could lead to deviations in the expansion behavior depending on the hydraulic properties of the stock solution (viscosity, density). This may have led to deviations in the actually aspirated volume.

We adjusted the nominal initial concentration $C_{\mathrm{A}, 0}^{*}$ with an empirical correction factor $C_{\mathrm{buffer}}$ so $C_{\mathrm{A}, 0}$ matched the concentration determined via HPLC using (5). The correction factor for droplets prepared with the solvent 2-MeTHF was $C_{\text {buffer }}=0.91$. The correction factor for the solvent DMSO was $C_{\text {buffer }}=0.96$.

$$
C_{\mathrm{A}, 0}=C_{\mathrm{A}, 0}^{*} \cdot C_{\mathrm{buffer}}
$$

While the systematic error of $4 \%$ to $9 \%$ between nominal and actual concentration in concentration could be corrected for $p$-tolyl triflate, there may also be similar systematic errors in the concentrations of N-H nucleophiles and/or bases. The error could not be corrected for these reagents because they were not retained in the reverse-phase chromatography column. Therefore, it was not possible to quantify their concentration.

\section{Optimization Runs}

An overview and detailed experimental raw data are given in the sheets "Optimization overview" and "Reaction data" in the attached Supplementary Excel file. The complete reaction conditions and resulting yield values are visualized in Fig. $6-9$. 

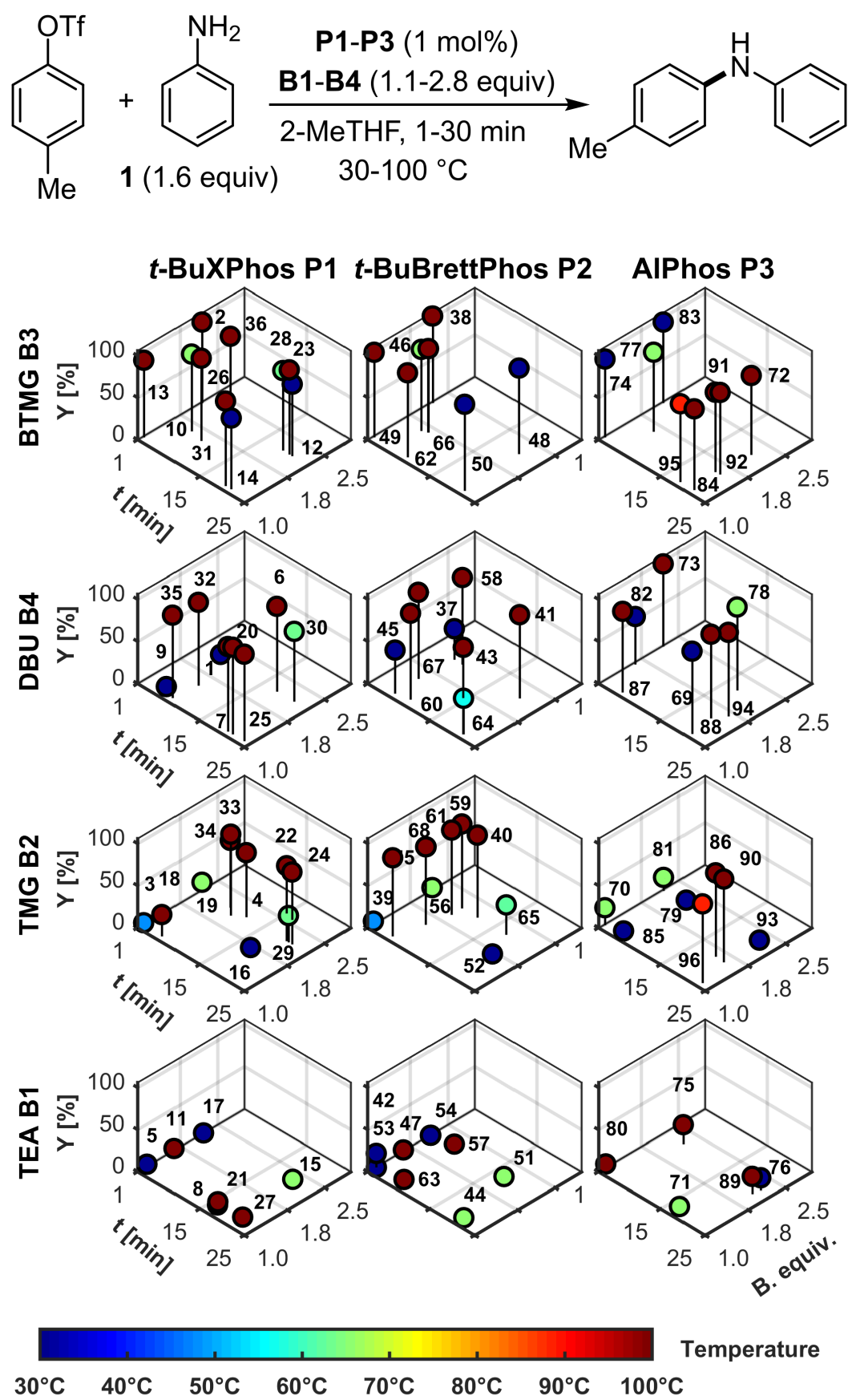

Figure S6: Aniline online optimization (all data points). Diagram position indicates the combination of base (line) and ligand (column). Continuous variable settings are represented by the position in the $x-y$ plane of the three-dimensional diagram (time, base equivalents) and the color bar (temperature). The resulting yield is indicated by the vertical position on the z-axis. Reaction numbers next to data points highlight the order of execution. Aniline was added to the reaction mixture by online injection instead of by the liquid handler. Reactions with more than $20 \%$ yield showed selectivity of $80 \%$ product or higher based on LC area integration. 

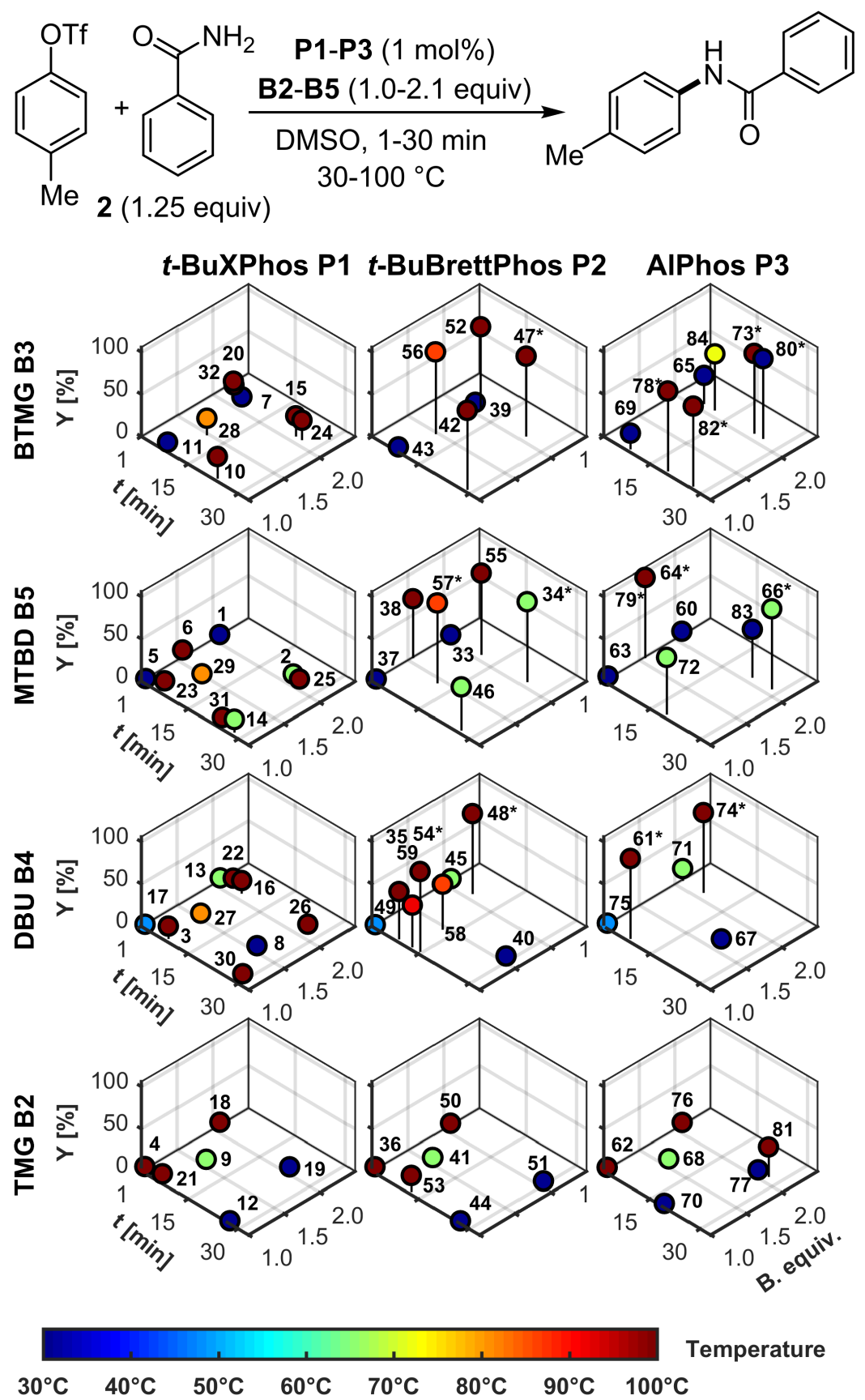

Figure S7: Benzamide online optimization (all data points). For the coupling of 2, the chromatographic separation was less effective for reactions with high product yields. For these cases, we observed a product peak tail in the UV signal that partially overlapped with the internal standard peak. This altered the peak ratio and lead to higher uncertainty for these data points and the response surface models. The chromatograms that featured this phenomenon showed nearly complete consumption of the aryl triflate starting material and no significant side products. Therefore, we can assume that the product yields and conversion are equal to or greater than $90 \%$ based on integration. Example chromatograms for a case with separated peaks (reaction 38) and a case with an overlapping peak tail (reaction 57) are given in Figure $\mathbf{S 8}$ and $\mathbf{S 9}$ below. 


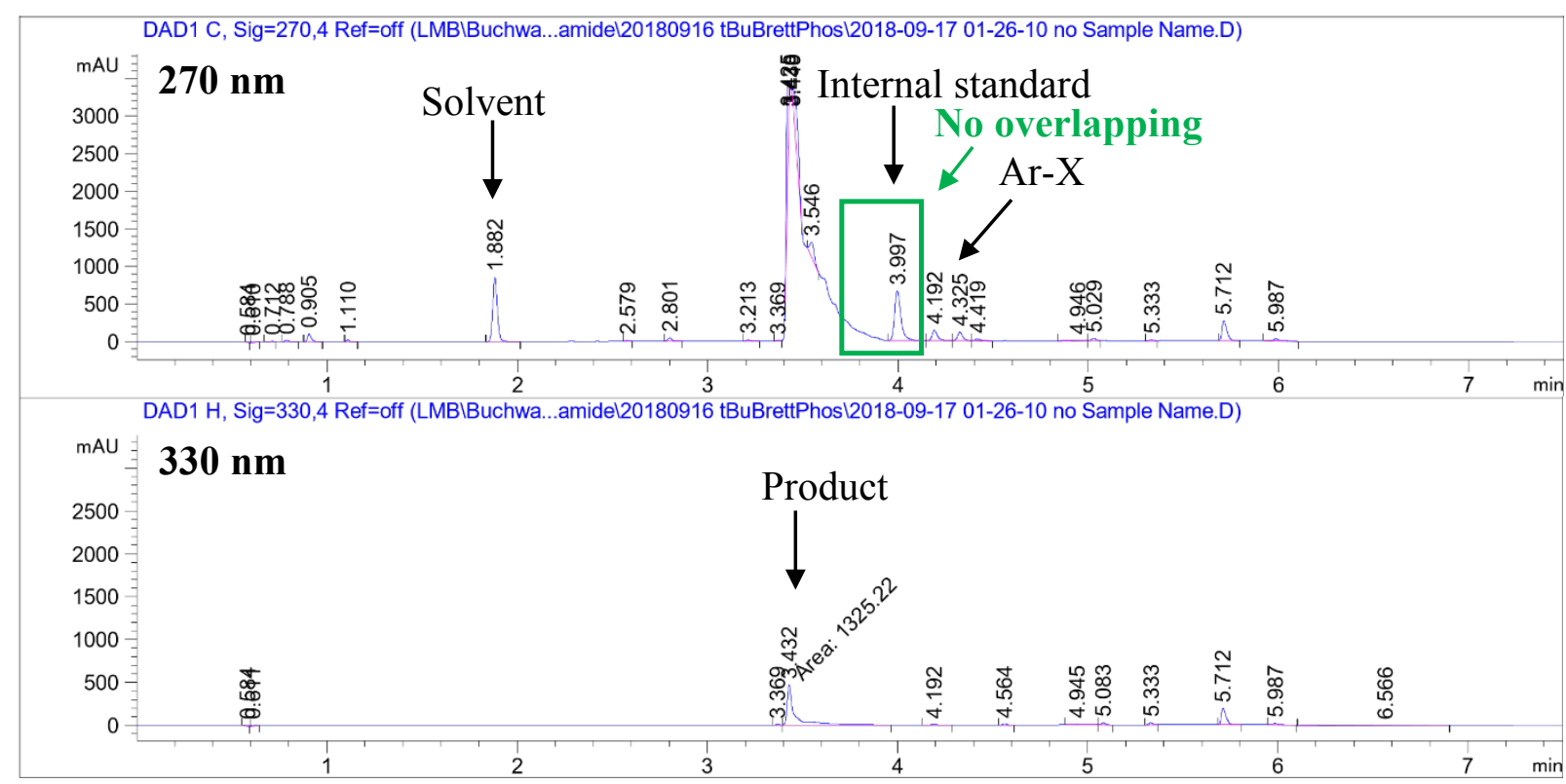

Figure S8: Reaction 38: Benzamide separation example with separated peaks. Reaction conditions: $t$-BuBrettPhos-bound precatalyst, 1.5 equiv. MTBD, $100{ }^{\circ} \mathrm{C}, 1.3 \mathrm{~min} .270 \mathrm{~nm}$ : Integration of internal standard (1-fluoronaphthalene) and $p$-tolyl triflate. $\mathbf{3 3 0} \mathbf{~ n m}$ : Integration of $N$-( $p$-tolyl) benzamide. Yield $=70 \%$, Conversion $=73 \%$.

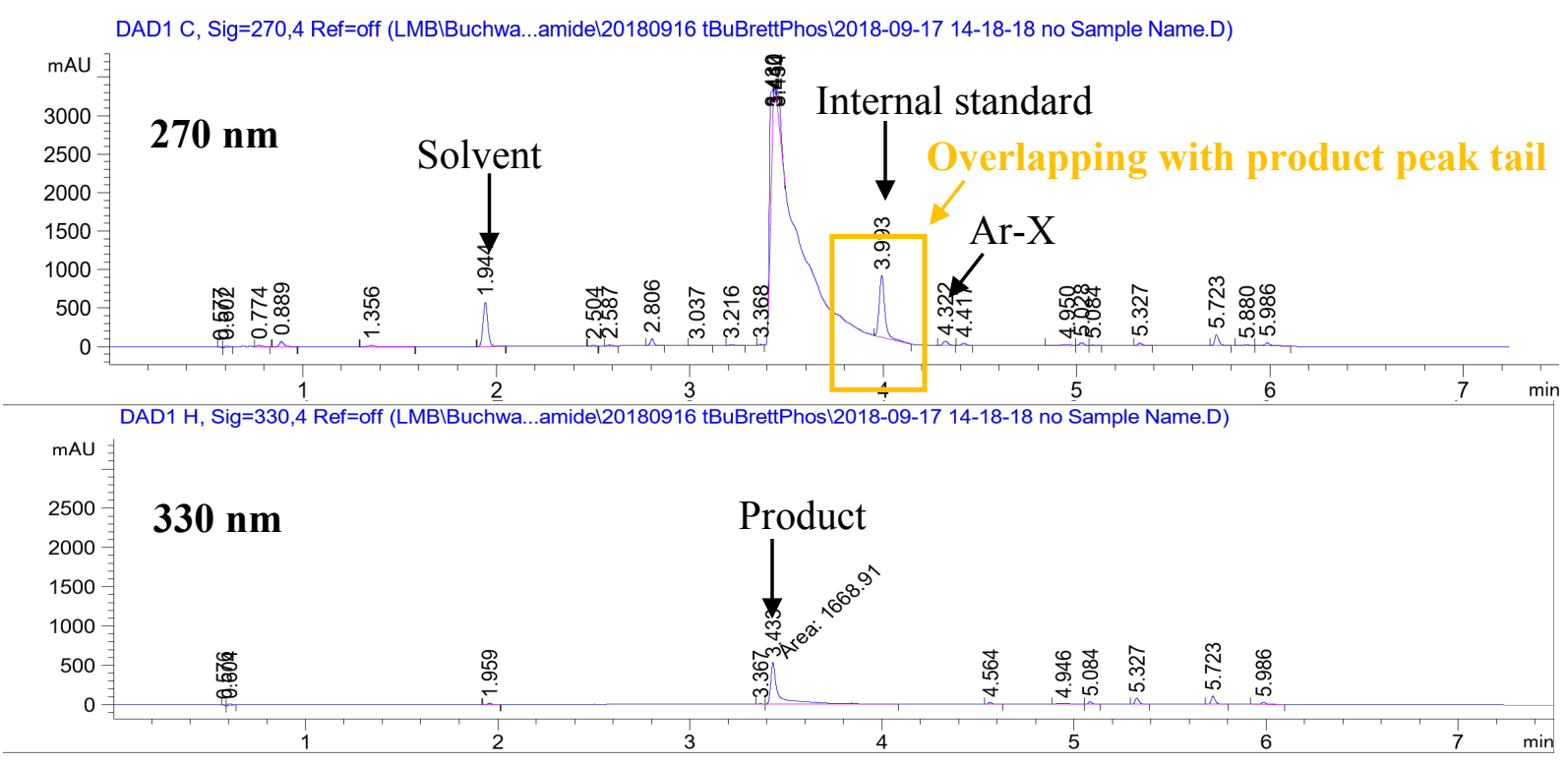

Figure S9: Reaction 57: Benzamide separation example with overlapping peak tail. Reaction conditions: $t$-BuBrettPhos-bound precatalyst, 1.4 equiv. MTBD, $87^{\circ} \mathrm{C}, 11.3 \mathrm{~min} . \mathbf{2 7 0} \mathbf{~ n m}$ : Integration of internal standard (1-fluoronaphthalene) and $p$-tolyl triflate. $330 \mathrm{~nm}$ : Integration of $N$-( $p$-tolyl)benzamide. Yield $\geq 90 \%$, Conversion $\geq 90 \%$. 

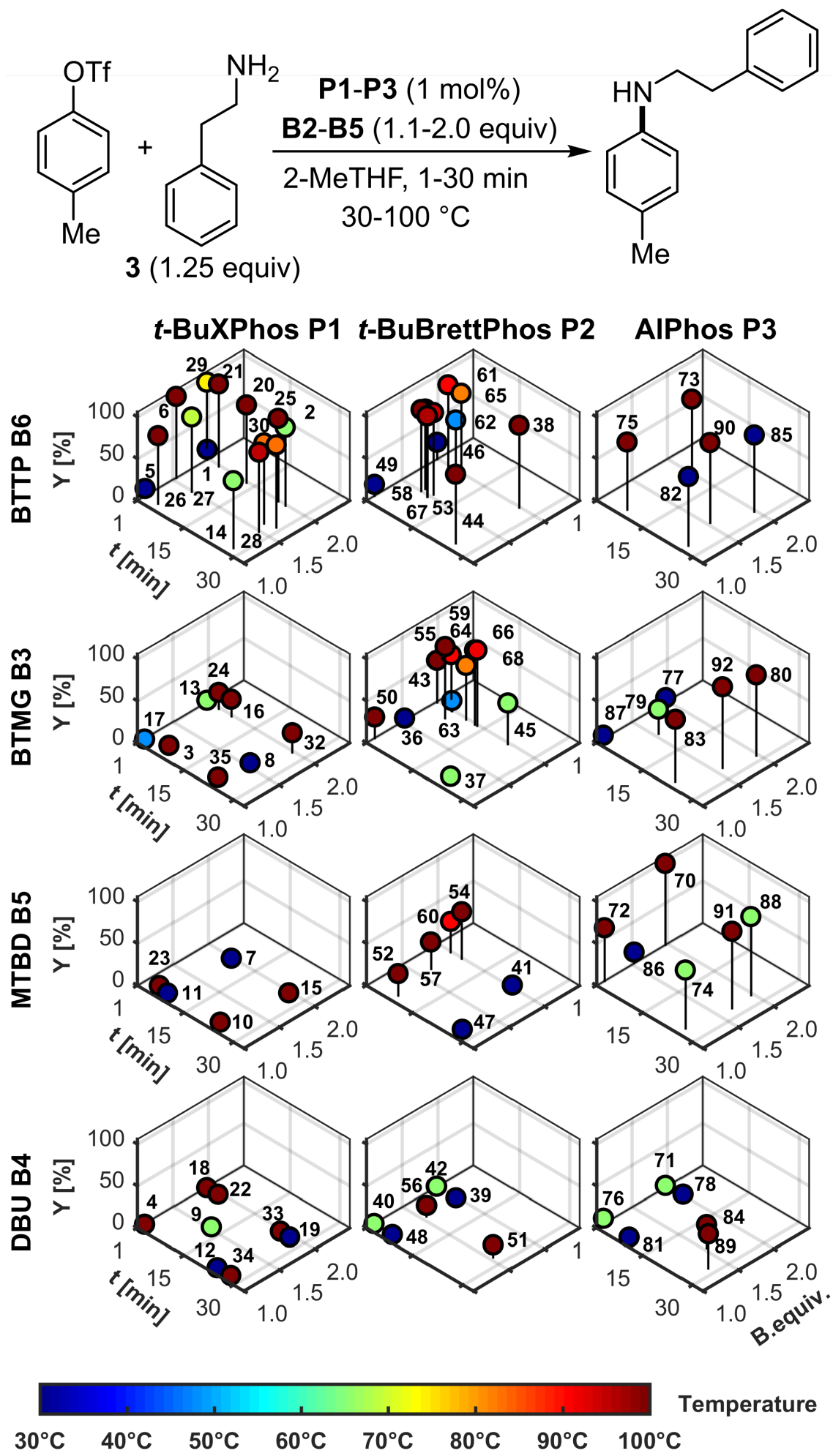

Figure S10: $\beta$-phenethylamine optimization (all data points). Reactions with more than 50\% yield showed selectivity of $90 \%$ or higher. 

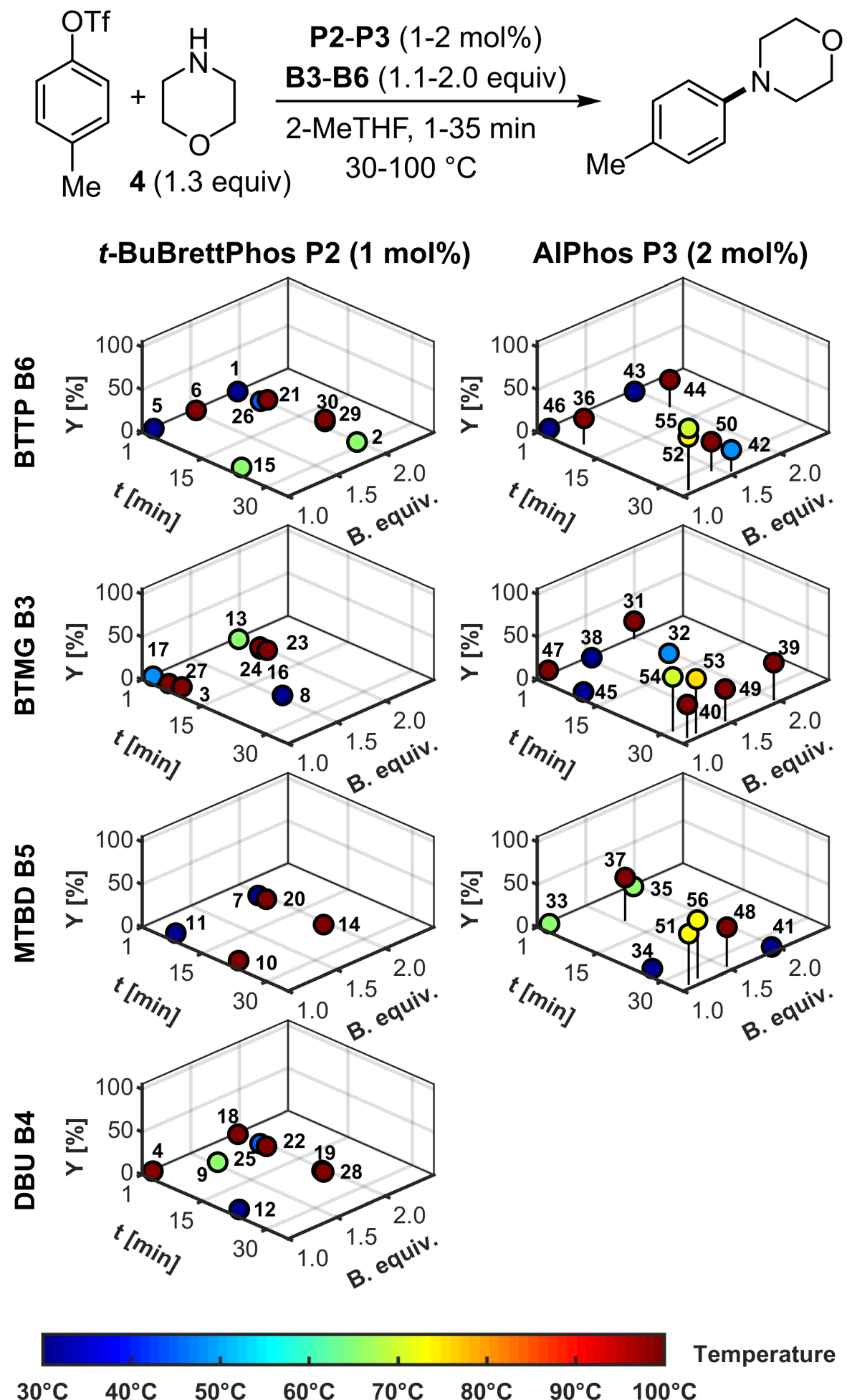

Figure S11: Morpholine Optimization (all data points). Based on preliminary experiments, the least promising precatalyst P1 was omitted, and the low-performing base DBU was not included in the P3. 


\section{Batch Scale Up of Reaction 48 (4 Optimization with P3).}

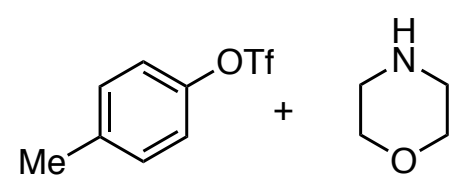

(S4, 1.2 eq.)

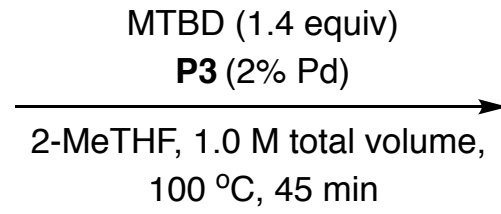

$100{ }^{\circ} \mathrm{C}, 45 \mathrm{~min}$

The reaction was performed outside of a nitrogen-filled glovebox. An oven-dried reaction tube (Fisher 16 x $125 \mathrm{~mm}$ tubes - Cat. No. 1495935A) equipped with a stir bar was charged with precatalyst P3 (44 mg, $47 \mu \mathrm{mmol}, 2.0 \mathrm{~mol} \% \mathrm{Pd}$ ). The reaction tube was sealed with a screw cap (Kimble Chase, Open Top S/T, Part No. 73804-15425) containing a Teflon septum (Thermo Scientific, 10/90 Teflon/Sil, Cat. No. B7995-15) and was pierced with a needle connected to a Schlenk line. The tube was evacuated and backfilled with nitrogen (this process was repeated a total of three times), then 2-MeTHF $(0.650 \mathrm{~mL}, 1.0 \mathrm{M}$ total reaction volume) was added via syringe. Under a positive pressure of nitrogen, $p$-tolyl triflate (measured density $=1.34 \mathrm{~g} / \mathrm{mL}, 420$ $\mu \mathrm{L}, 2.35 \mathrm{mmol}, 1.0$ equiv), morpholine (245 $\mu \mathrm{L}, 2.90 \mathrm{mmol}, 1.23$ equiv), and 7-methyl-1,5,7triazabicyclo[4.4.0]dec-5-ene (MTBD, B5, $3.25 \mathrm{mmol}, 465 \mu \mathrm{L}, 2.38$ equiv) were sequentially added via syringe. The reaction mixture was placed in an oil bath preheated to $100{ }^{\circ} \mathrm{C}$. As a precautionary measure, a blast shield was placed in front of the reaction vessel during the heating process. The reaction mixture was stirred at this temperature for $45 \mathrm{~min}$. After this time, the reaction mixture was allowed to cool to room temperature, diluted with $\mathrm{CH}_{2} \mathrm{Cl}_{2}$, transferred to a round bottom flask, and concentrated with the aid of a rotary evaporator. The crude reaction mixture was analyzed by ${ }^{1} \mathrm{H}$ NMR (95\% conversion) and then was purified by automated silica gel column chromatography (50 g silica gel, 0-20\% EtOAc in hexanes, 12 column volumes) to afford white crystals (226 mg, 54\% yield).

${ }^{1}$ H NMR $\left(400 \mathrm{MHz} ; \mathrm{CDCl}_{3}\right) \delta 7.11(\mathrm{~d}, J=8.2 \mathrm{~Hz}, 2 \mathrm{H}), 6.85(\mathrm{~d}, J=8.2 \mathrm{~Hz}, 2 \mathrm{H}), 3.91-3.82(\mathrm{~m}$, 4H), 3.16 - 3.08 (m, 4H), 2.30 (s, 3H). $\left.{ }^{13} \mathbf{C ~ N M R ~ ( 1 0 1 ~ M H z , ~} \mathrm{CDCl}_{3}\right) \delta$ 149.32, 129.81, 129.64, 116.13, 67.09, 50.03, 20.53. IR (neat, $\mathrm{cm}^{-1}$ ): 2976.9, 2852.2, 1511.8, 1451.7, 1115.9, 921.3, 817.8. MP: $44.3-46.2{ }^{\circ} \mathrm{C}$. 


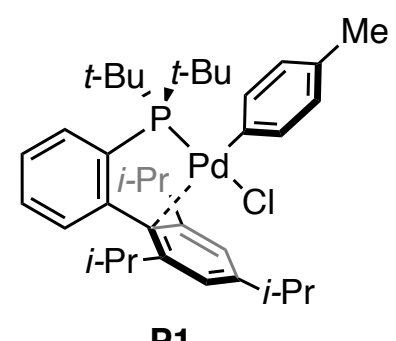

P1

${ }^{1} \mathrm{H} N M R$

$\mathrm{CDCl}_{3}$

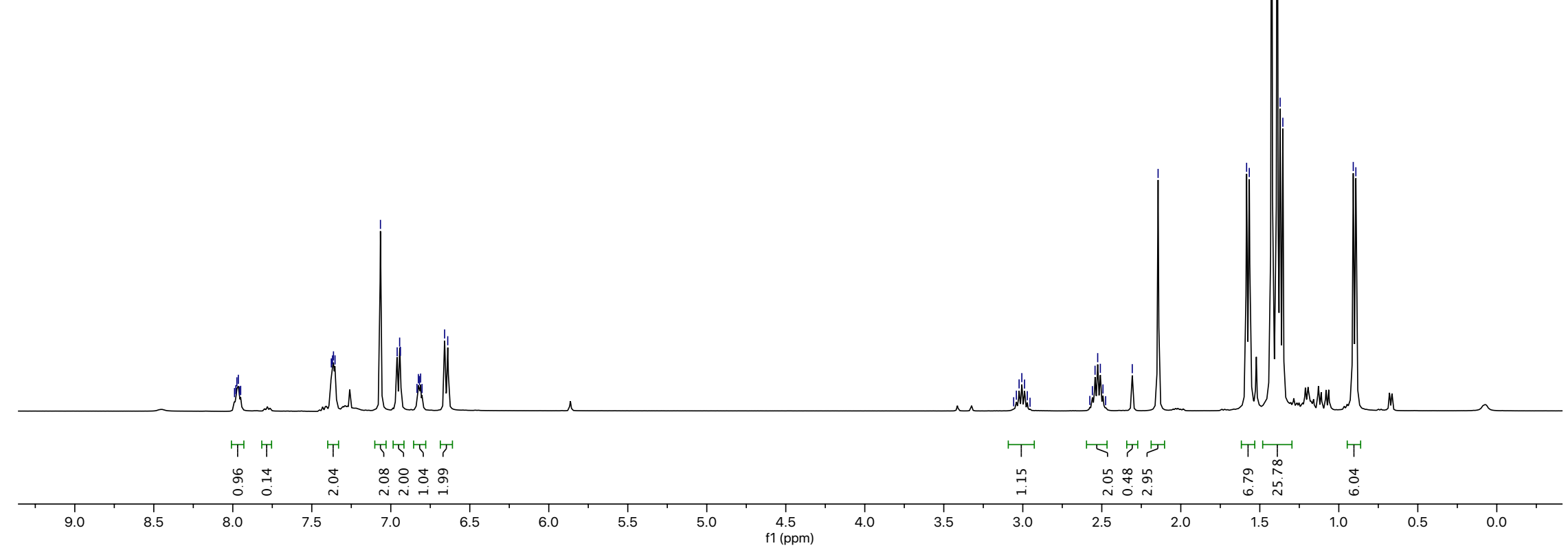




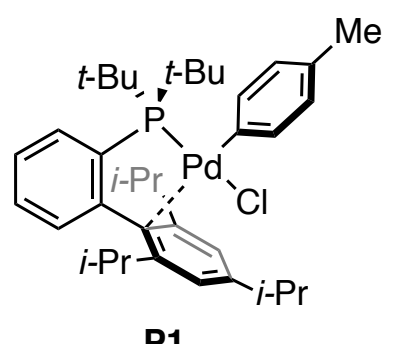

${ }^{13} \mathrm{C}$ NMR

$\mathrm{CDCl}_{3}$

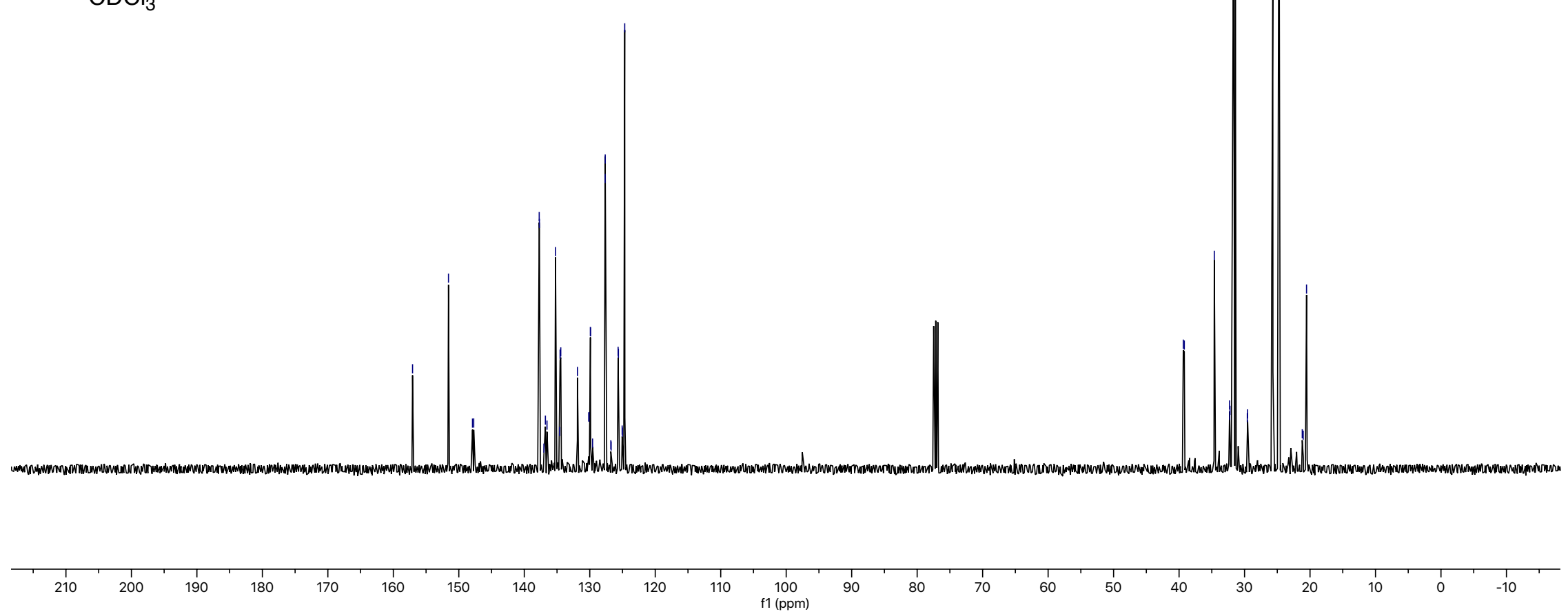



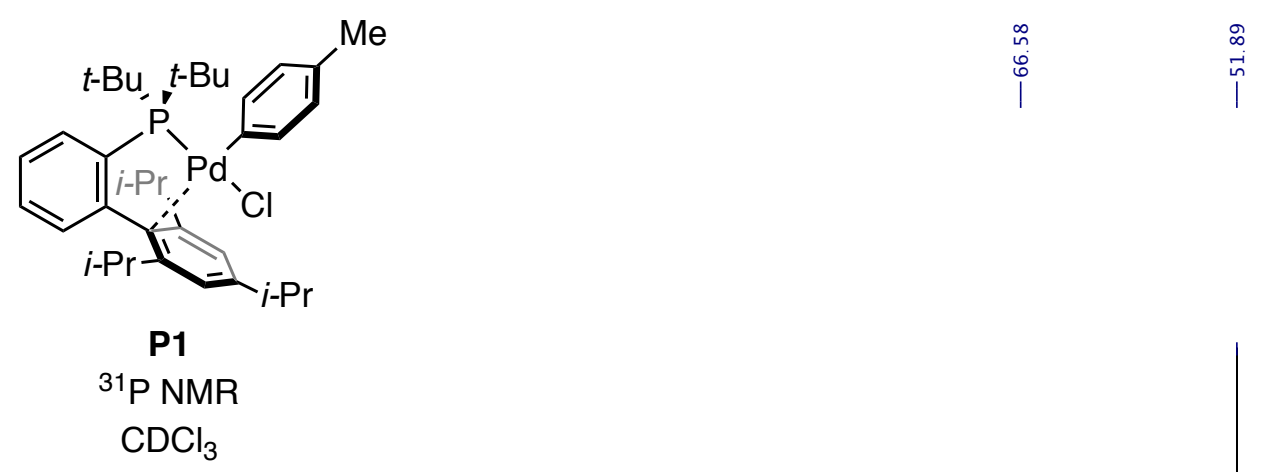

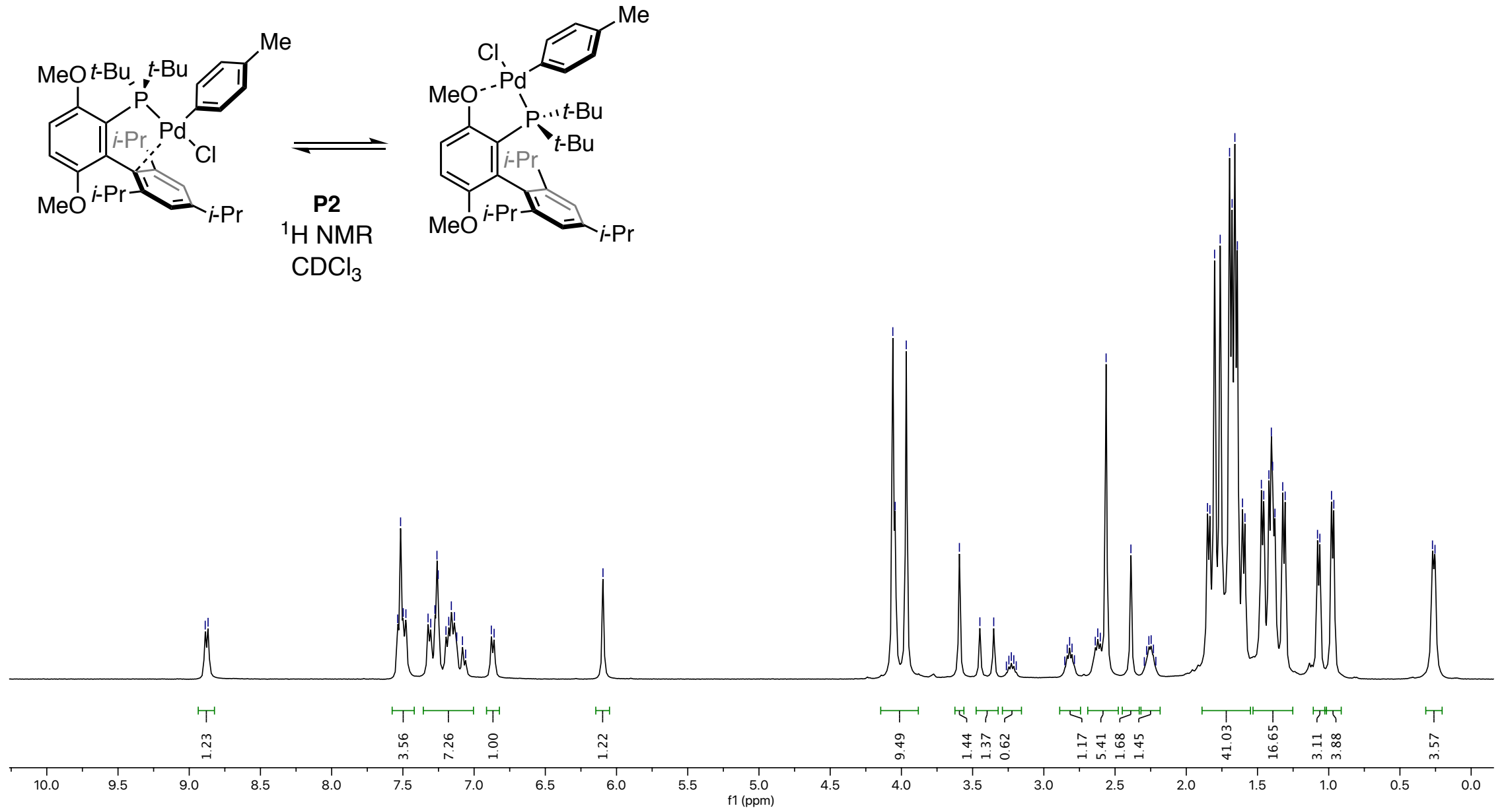

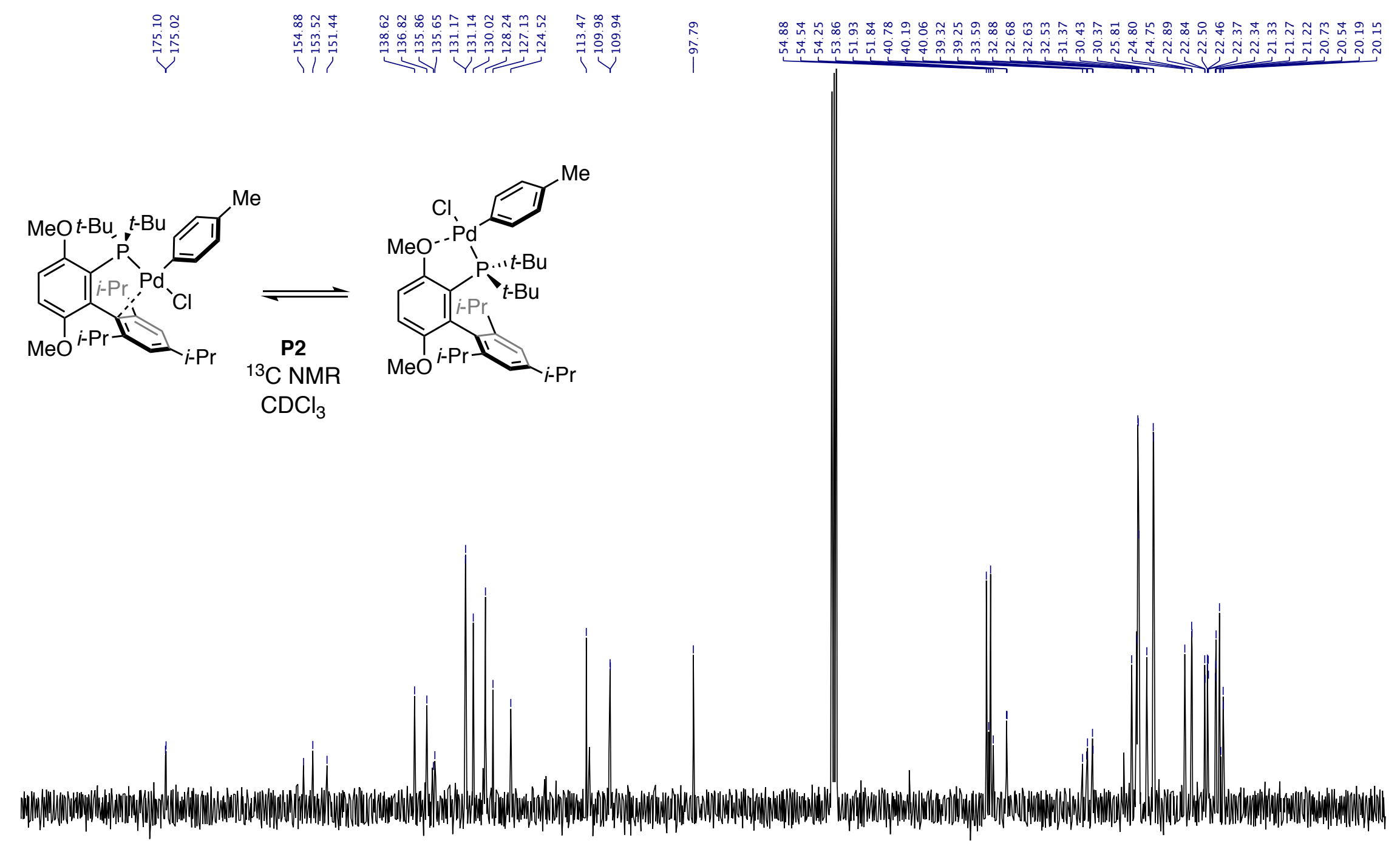

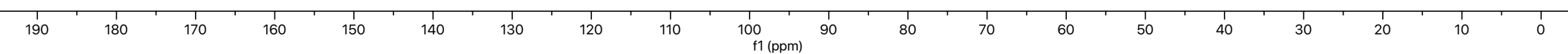



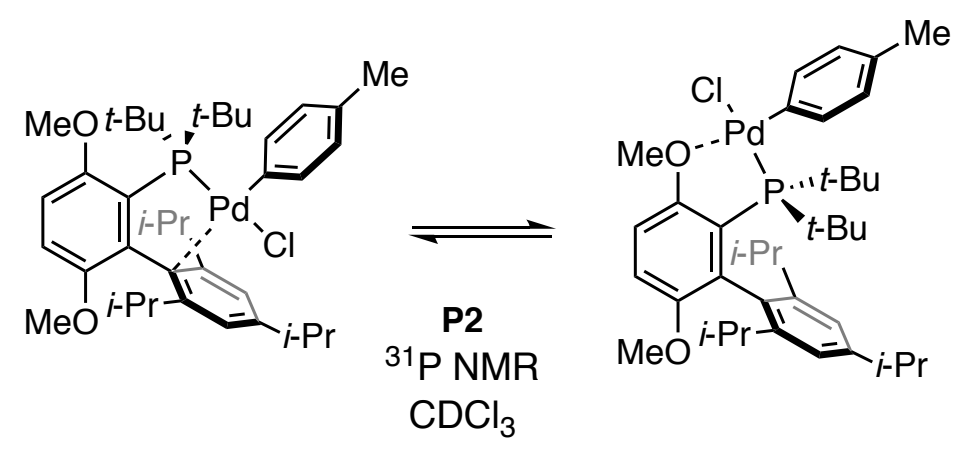

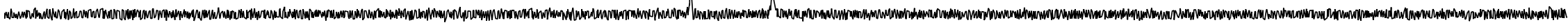

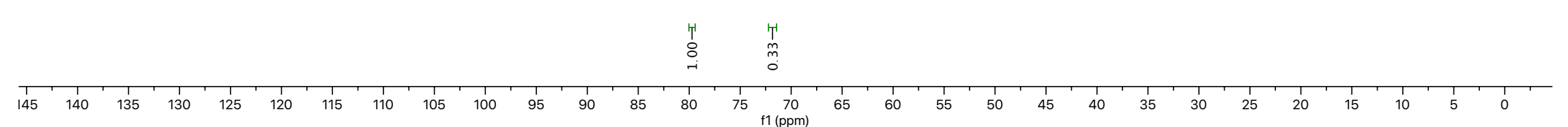




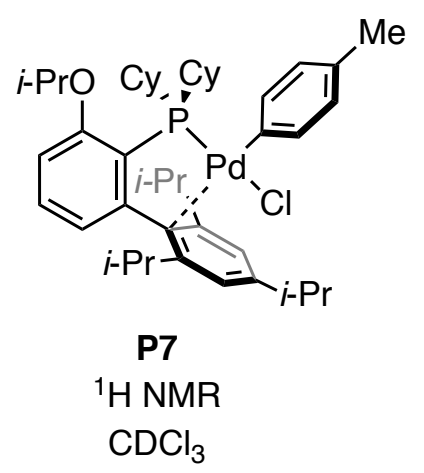



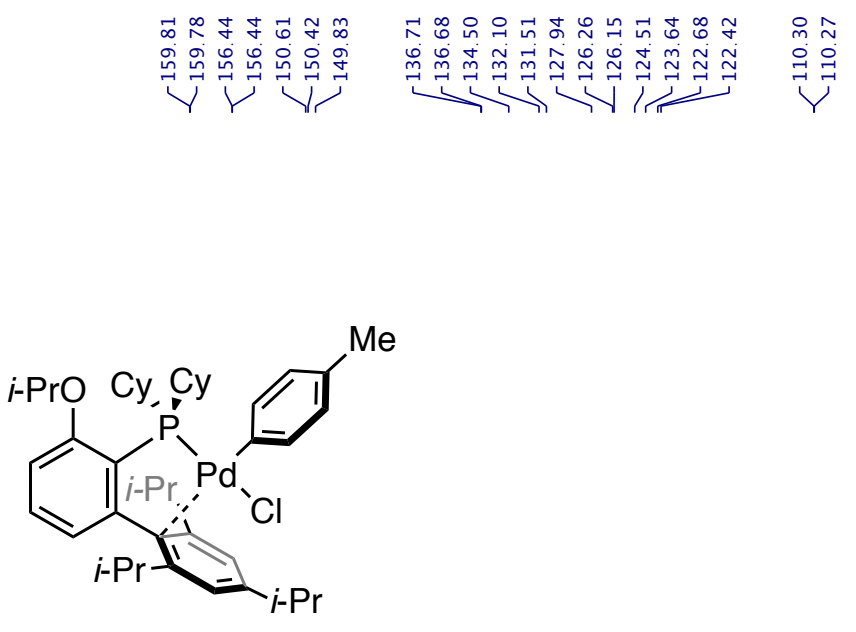

P7

${ }^{13} \mathrm{C}$ NMR

$\mathrm{CDCl}_{3}$

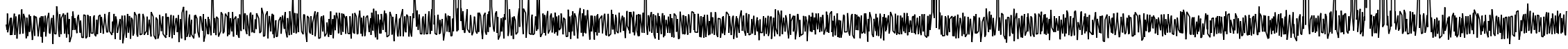




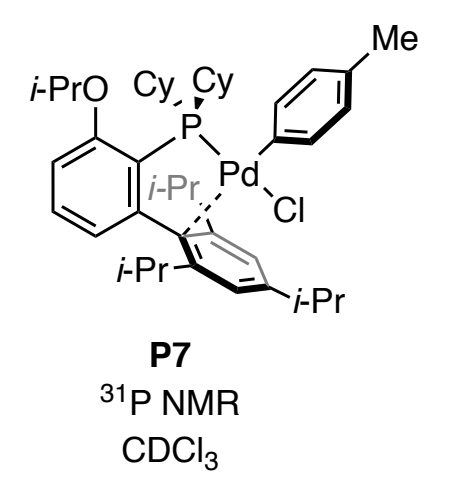




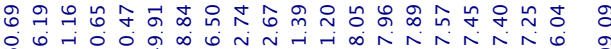

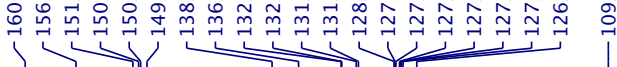

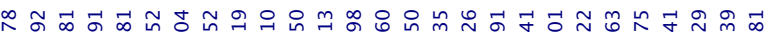

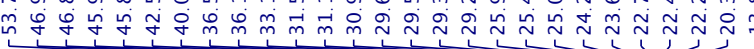

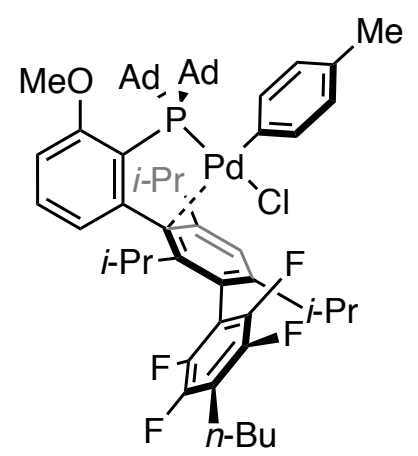

P3

${ }^{13} \mathrm{C}$ NMR

$\mathrm{CDCl}_{3}$

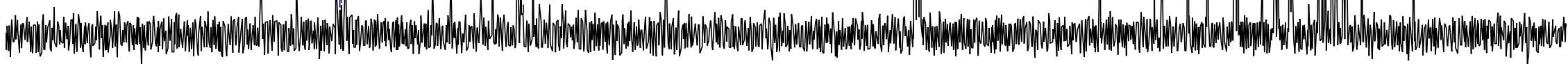




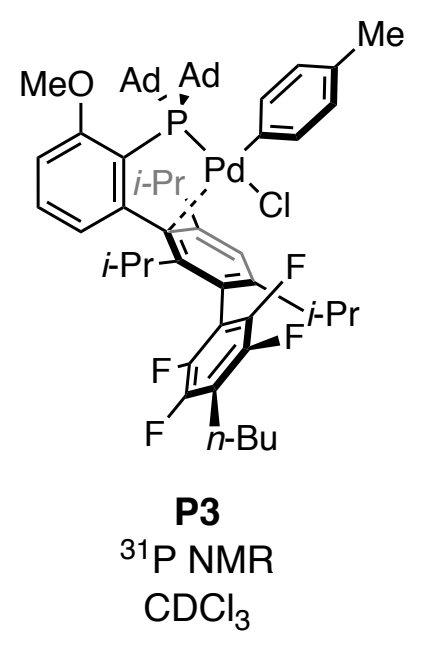

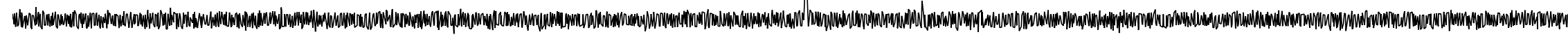



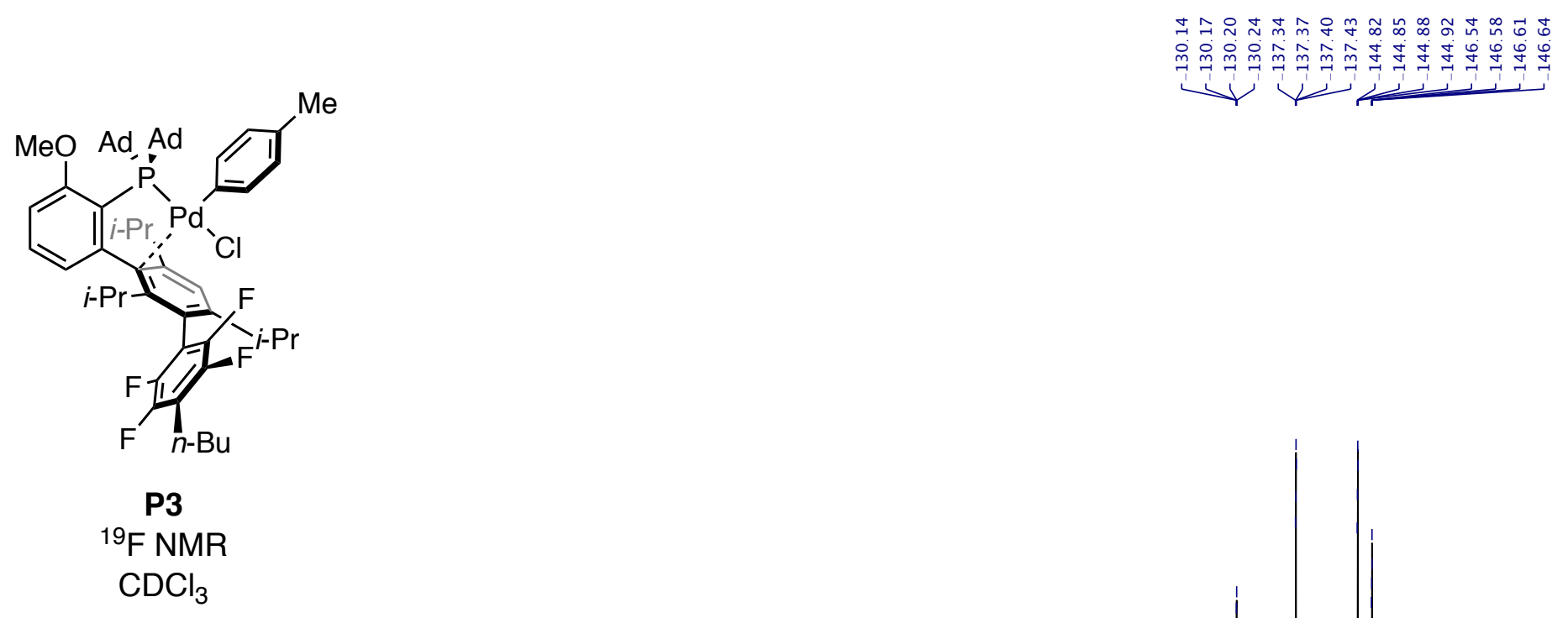

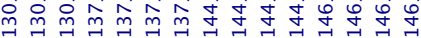

$\mathrm{CDCl}_{3}$

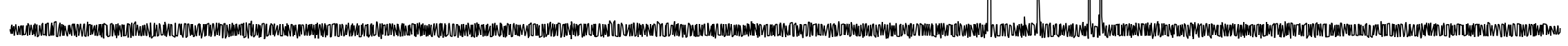

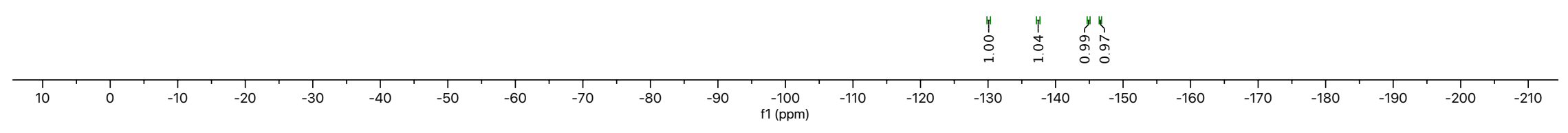




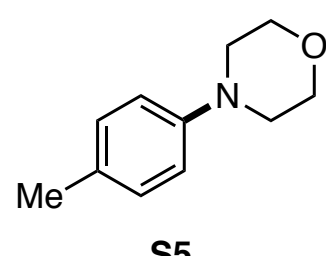

S5

${ }^{1} \mathrm{H} N M R$

$\mathrm{CDCl}_{3}$

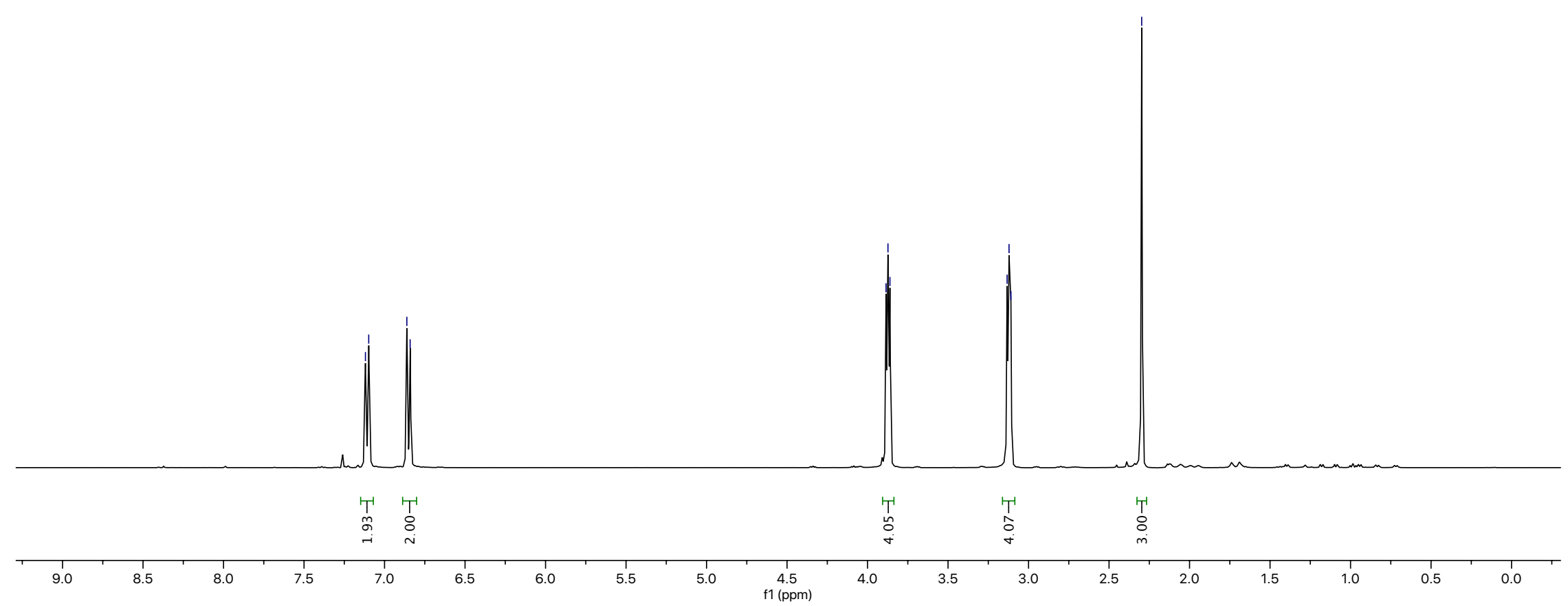



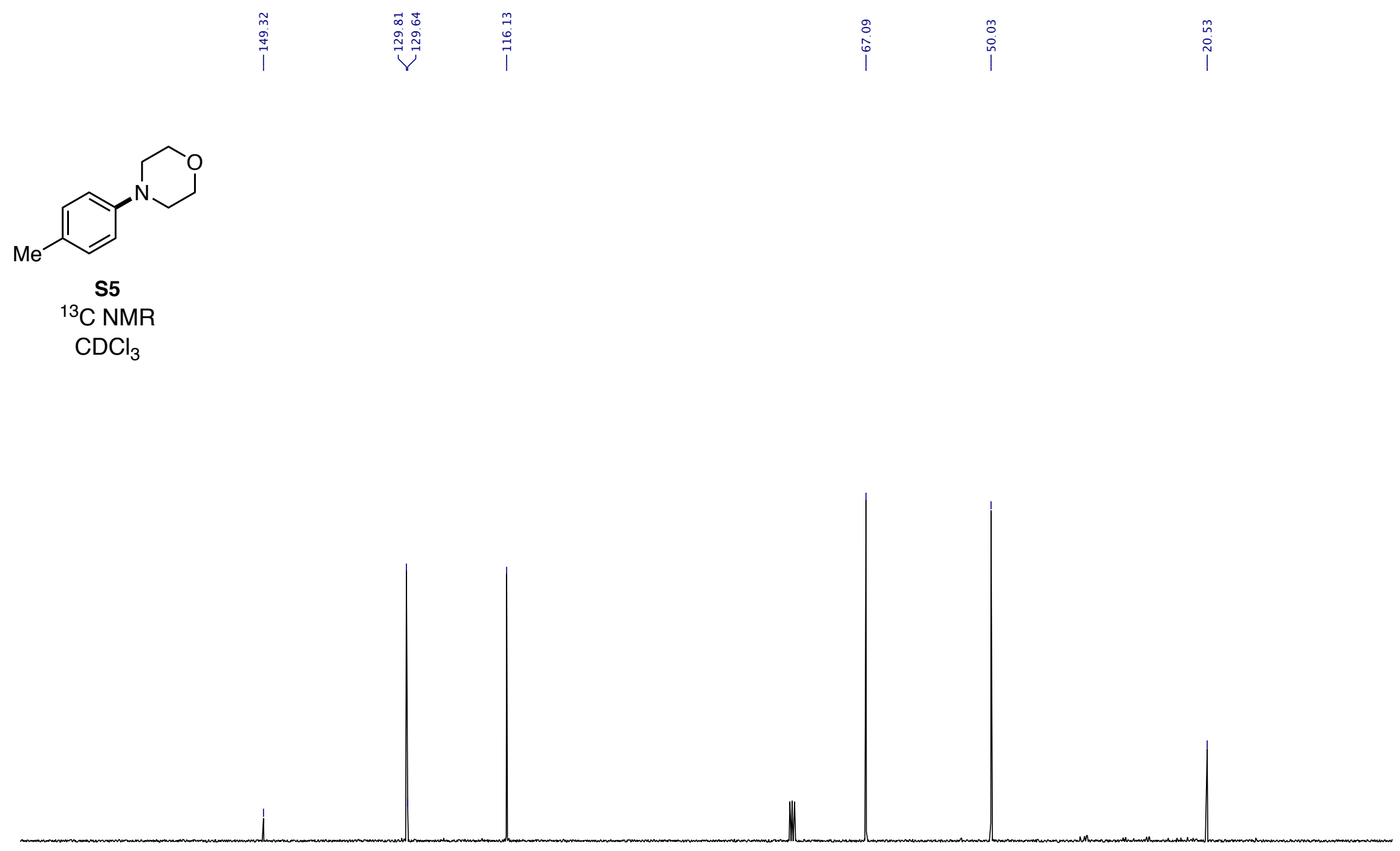


\section{$\underline{\text { References }}$}

(1) Kampmann, S. S.; Sobolev, A. N.; Koutsantonis, G. A.; Stewart, S. G. Stable Nickel(0) Phosphites as Catalysts for C-N Cross-Coupling Reactions. Ad. Synth. Catal. 2014, 356, 19671973.

(2) A $t$-BuBrettPhos G3 precatalyst was used instead of $\mathrm{Pd}(\mathrm{OAc})_{2}$. See: Fors, B. P.; Dooleweerdt, K.; Zeng, Q.; Buchwald, S. L. An Efficient System For the Pd-Catalyzed CrossCoupling of Amides and Aryl Chlorides. Tetrahedron 2009, 65, 6576-6583.

(3) Maiti, D.; Fors, B. P.; Henderson, J. L.; Nakamura, Y.; Buchwald, S. L. Palladium-Catalyzed Coupling of Functionalized Primary and Secondary Aminrs with Aryl and Heteroaryl Halides: Two Ligands Suffice in Most Cases. Chem. Sci., 2011, 2, 57.

(4) Fors, B. P.; Buchwald, S. L. A Multilgand Based Pd Catalyst for C-N Cross-Coupling Reactions. J. Am. Chem. Soc. 2010, 132, 15914-15917.

(5) De, S.; Yin, J.; Ma, D. Copper-Catalyzed Coupling Reaction of (Hetero)Aryl Chlorides and Amides. Org. Lett., 2017, 19, 4864-4867.

(6) Cui, X.; Dai, X.; Deng, Y.; Shi, F. Development of a General Non-Noble Metal Catalyst for the Benign Amination of Alcohols with Amines and Ammonia. Chem. Eur. J., 2013, 19, 36653675 .

(7) Zhang, Y.; César, V.; Storch, G.; Lugan, D.; Lavigne, G. Skeleton Decoration of NHCs by Amino Groups and its Sequential Booster Effect on the Palladium-Catalyzed Buchwald-Hartwig Amination. Angew. Chem. Int. End. 2014, 53, 6482-6486.

(8) Dennis, J. M. White, N. A.; Liu, R. Y.; Buchwald, S. L. Breaking the Base Barrier: An Electron-Deficient Palladium Catalyst Enables the Use of a Common Soluble Base in C-N Coupling. J. Am. Chem. Soc. 2018, 140, 4721-4725.

(9) Lee, H. G.; Milner, P. J.; Buchwald, S. L. An Improved System for the Pd-Catalyzed Fluorination of (Hetero)Aryl Triflates. Org. Lett., 2013, 15, 5602-5605.

(10) Baumgartner, L. M.; Coley, C. W.; Reizman, B. J.; Gao, K. W.; Jensen, K. F. Optimum Catalyst Selection Over Continuous and Discrete Process Variables with a Single Droplet Microfluidic Reaction Platform. React. Chem. Eng. 2018, 3, 301-311.

(11) For a discussion on and application of slurry additions of precatalyst mixtures, see: Sperry, J. B.; Price Wiglesworth, K. E.; Edmonds, I.; Fiore, P.; Boyles, D. C.; Damon, D. B.; Dorow, R. L.; Piatnitski Chekler, E. L.; Langille, J.; Coe, J. W. Kiloscale Buchwald-Hartwig Amination: Optimized Coupling of Base-Sensitive 6-Bromoisoquinoline-1-carbonitrile with (S)-3-Amino-2methylpropan-1-ol. Org. Process Res. Dev. 2014, 18, 1752-1758. 